\title{
An Explanation of Negative Swap Spreads Demand for Duration from Underfunded Pension Plans
}

Klingler, Sven; Sundaresan, Suresh

Document Version

Accepted author manuscript

Published in:

Journal of Finance

DOI:

10.1111/jofi.12750

Publication date:

2019

License

Unspecified

Citation for published version (APA):

Klingler, S., \& Sundaresan, S. (2019). An Explanation of Negative Swap Spreads: Demand for Duration from Underfunded Pension Plans. Journal of Finance, 74(2), 675-710. https://doi.org/10.1111/jofi.12750

Link to publication in CBS Research Portal

\section{General rights}

Copyright and moral rights for the publications made accessible in the public portal are retained by the authors and/or other copyright owners and it is a condition of accessing publications that users recognise and abide by the legal requirements associated with these rights.

Take down policy

If you believe that this document breaches copyright please contact us (research.lib@cbs.dk) providing details, and we will remove access to the work immediately and investigate your claim. 


\title{
An Explanation of Negative Swap Spreads: Demand for Duration from Underfunded Pension Plans
}

\section{Sven Klingler and Suresh Sundaresan}

\author{
Journal article (Accepted manuscript*)
}

\section{Please cite this article as:}

Klingler, S., \& Sundaresan, S. (2019). An Explanation of Negative Swap Spreads: Demand for Duration from Underfunded Pension Plans. Journal of Finance, 742), 675-710. https://doi.org/10.1111/jofi.12750

This is the peer reviewed version of the article, which has been published in final form at DOI: https://doi.org/10.1111/jofi.12750

This article may be used for non-commercial purposes in accordance with Wiley Terms and Conditions for Self-Archiving

* This version of the article has been accepted for publication and undergone full peer review but has not been through the copyediting, typesetting, pagination and proofreading process, which may lead to differences between this version and the publisher's final version AKA Version of Record. 


\title{
An Explanation of Negative Swap Spreads: Demand for Duration from Underfunded Pension Plans
}

\author{
SVEN KLINGLER and SURESH SUNDARESAN*
}

Journal of Finance forthcoming

\begin{abstract}
The 30-year U.S. swap spreads have been negative since September 2008. We offer a novel explanation for this persistent anomaly. Through an illustrative model, we show that underfunded pension plans optimally use swaps for duration hedging. Combined with dealer banks' balance sheet constraints, this demand can drive swap spreads to become negative. Empirically, we construct a measure of the aggregate funding status of Defined Benefit pension plans and show that this measure is a significant explanatory variable of 30-year swap spreads. We find a similar link between pension funds' underfunding and swap spreads for two other regions.
\end{abstract}

\footnotetext{
${ }^{*}$ Klingler (corresponding author) is from the Department of Finance, BI Norwegian Business School and Sundaresan is from Columbia Business School. We are grateful to Stefan Nagel (the Editor), the Associate Editor, two anonymous referees, Darrell Duffie, Robin Greenwood, Wei Jiang, Tomas Kokholm, David Lando, Harry Mamaysky, Scott McDermott, Stephen Schaefer, Pedro Serrano, Morten Sørensen, Hyun Shin, Savitar Sundaresan, and Dimitri Vayanos for helpful comments. Klingler acknowledges support from the Center for Financial Frictions (FRIC), grant no. DNRF102. Sundaresan acknowledges with thanks the productive sabbatical spent at BIS where the paper received useful suggestions and comments. We also thank participants in the seminars at the Swiss Finance Institute in Gerzensee and at the Indian School of Business for their comments. The authors have no conflicts of interest, as identified in the Disclosure Policy.
} 
In September 2008, shortly after the default of Lehman Brothers, the difference between the swap rate (which is the fixed-rate in the swap) of a 30-year interest rate swap (IRS) and the yield of a Treasury bond with the same maturity, commonly referred to as swap spread, dropped sharply and became negative. As we explain in more detail later, this is a theoretical arbitrage opportunity and an asset pricing anomaly. In contrast to other crises phenomena, the 30-year negative swap spread is very persistent and still at around -40 basis points as of December 2015. In this paper, we examine the persistent negative 30-year swap spread and offer a new perspective on the possible reasons behind this anomaly. Our hypothesis is that demand for duration hedging by underfunded pension plans coupled with balance sheet constraints faced by swap dealers puts pressure on long-term swap fixed rates and ultimately turned the 30-year swap spread to become negative.

Negative swap spreads are a pricing anomaly and present a challenge to views that have been held prior to the financial crisis that suggested that swap spreads are indicators of market uncertainty, which increase in times of financial distress. This is because the fixed payment in an IRS is exchanged against a floating payment, which is typically based on Libor, and entails credit risk. Hence, even though IRS are collateralized and viewed as free of counterparty credit risk, the swap rate should be above the (theoretical) risk-free rate because of the credit risk that is implicit in Libor. Therefore, swap spreads should increase in times of elevated bank credit risk (see Collin-Dufresne and Solnik, 2001, for a treatment of this and related issues). In addition to that, treasuries (which are the benchmarks against which swap spreads are computed) have a status as "safe haven", i.e., assets that investors value for their safety and liquidity. In times of financial distress, investors value the convenience of holding safe and liquid assets even more, which decreases the treasury yield and makes them trade at a liquidity premium or convenience yield (see, for instance, Longstaff, 2004, 
Krishnamurthy and Vissing-Jorgensen, 2012, or Feldhütter and Lando, 2008). In summary, these arguments show that the 30-year swap spread should have increased around the default of Lehman Brothers.

We offer a demand-driven explanation for negative swap spreads. In particular, we develop a model in which underfunded pension plans' demand for duration hedging leads them to optimally receive the fixed rate in IRS with long maturities. Pension funds have long-term liabilities in the form of unfunded pension claims and invest in a portfolio of assets, such as stocks, as well as in other long-term assets, like government bonds. They can balance their asset-liability duration by investing in long-term bonds or by receiving fixed in an IRS with long maturity. Our theory predicts that, if pension funds are underfunded, they prefer to hedge their duration risk with IRS rather than buying Treasuries, which may be not feasible given their funding status. The preference for IRS to hedge duration risk arises because the swap requires only modest investment to cover margins, whereas buying a government bond to match duration requires outright investment. ${ }^{1}$ This demand, when coupled with dealer balance sheet constraints results in negative swap spreads.

Greenwood and Vayanos (2010) show that pension funds' demand for duration hedging in the U.K. can affect the term structure of British gilts by lowering long-term rates. In this sense, our paper bears a close relationship to their work. However, our approach differs from theirs since we focus on underfunded pension funds' optimal preference for the use of IRS for duration hedging. The model that we develop shows that the demand for IRS increases as the fund becomes more underfunded.

We provide non-parametric evidence suggesting that the swap spreads tend to be negative in periods when DB plans are underfunded. We thus illustrate a new channel that may be at work in driving long-term swap spreads down. Using data from the financial accounts 
of the United States (former flow of funds table) from the Federal Reserve, we construct a measure of the aggregate funding status of DB plans (both private and public) in the United States. We then use this measure to test the relationship between the underfunded ratio (UFR) of DB plans and long-term swap spreads in a regression setting. Even after controlling for other common drivers of swap spreads, recognized in the literature, such as the spread between Libor and repo rates, Debt-to-GDP ratio, dealer-banks' financial constraints, market volatility, and level as well as the slope of the yield curve, we find that $U F R$ is a significant variable in explaining 30-year swap spreads. In line with our narrative, we also show that swap spreads of shorter maturities are not affected by changes in UFR.

We conduct a number of robustness tests. One potential concern about using $U F R$ as an explanatory variable for swap spreads is that the same factors that have been shown to affect swap spreads can also affect pension funds. For example, a decrease in the level of the yield curve can affect swap spreads and also increases the level of pension funds' underfunding. To address this concern, we use stock returns as an instrumental variable in a two-stage least square setting. The idea here is that stock returns directly affect pension funds' funding status (through the asset side) but there is no obvious economic reason as to why they are related to swap spreads. Our results are robust to this additional test. Next, we add different control variables, such as U.S. corporate bond issuance, and also test the effect of pension fund's underfunding on swap spreads in different time periods. We find that the link between $U F R$ and swap spreads is most pronounced in the immediate aftermath of Lehman Brother's default, when derivatives dealers faced stringent balance sheet constraints. Finally, we test the effect of a modified version of $U F R$ on swap spreads and find that our results are robust to this modification.

We conclude our paper by testing the effect of pension funds' underfunding on swap 
spreads in two additional countries with significant pension plans: Japan and the Netherlands. Here, we find that the funding status of Japanese pension funds is a significant explanatory variable for Japanese swap spreads with 10 years and 30 years to maturity. Moreover, Dutch pension funds' funding status is also a significant explanatory variable for 30-year swap spreads in Europe. Next, we review the related literature.

As mentioned above, Greenwood and Vayanos (2010) show that the demand pressure by pension funds lowers long-term yields of British gilts. In addition, Greenwood and Vayanos (2010) mention that pension funds also fulfill their demand for long-dated assets by using derivatives to swap fixed for floating payments. They note that pension funds have "swapped as much as $£ 50$ billion of interest rate exposure in 2005 and 2006 to increase the duration of their assets" but do not investigate the impact of such demand on swap spreads any further. Their focus was on U.K. Gilt markets. Hence, our paper complements their analysis by showing that underfunded pension funds' demand for long-dated assets can have a strong impact on swap rates, globally.

More generally, swap rates and treasury yields have been studied extensively in the previous literature. A stream of literature calibrates dynamic term-structure models to understand the dynamics of swap spreads (see Duffie and Singleton, 1997, Lang, Litzenberger, and Liu, 1998, Collin-Dufresne and Solnik, 2001, Grinblatt, 2001, Liu, Longstaff, and Mandell, 2006, Johannes and Sundaresan, 2007, and Feldhütter and Lando, 2008, among others). Amongst these papers, the paper close in spirit to our paper is Feldhütter and Lando (2008). They decompose swap spreads into three components, credit risk in Libor, the convenience yield of government bonds, and a demand-based component. In contrast to our paper, their study focuses on maturities between one and ten years and they link the demand-based component to duration hedging in the mortgage market. 
The usage of swaps by non-financial companies has been studied by, among others, Faulkender (2005), Chernenko and Faulkender (2012), Jermann and Yue (2013). We focus on pension funds' underfunding issues, which have been studied by, among others, Sundaresan and Zapatero (1997) and Ang, Chen, and Sundaresan (2013). We add to this literature by linking changes in swap spreads to changes in pension fund underfunding.

We note that any demand-based explanation would be incomplete if there were no financial frictions for the supply of IRS. Hence, we also build on the literature of limits of arbitrage (Shleifer and Vishny, 1997, Gromb and Vayanos, 2002, Liu and Longstaff, 2004, Gromb and Vayanos, 2010, Gârleanu and Pedersen, 2011, among many others) and especially the literature on dealer constraints and demand pressure in the derivatives market Garleanu, Pedersen, and Poteshman, 2009).

To the best of our knowledge, we are the first to offer a demand-based explanation for negative swap spreads. Jermann (2016) studies the negative swap spreads, offering frictions for holding long-term bonds as an explanation but taking the demand for swaps as exogenously given. In his model, Jermann (2016) assumes that holding bonds is costly and shows that, as the holding costs increase, the swap rate converges to the Libor rate, which is typically below the long-term Treasury yield. Our explanation is distinct from his work, as the $U F R$ measure of underfunded status of $\mathrm{DB}$ pension plans is a significant variable in explaining 30-year swap spreads but not for swap spreads with other maturities. Furthermore, controlling for term spreads leaves our main results unchanged. Holding outright long positions in bonds for under-funded pension plans to match duration has an opportunity cost in practice and this is what we stress in our work. Lou (2009) also offers derivatives dealers' funding costs as an explanation of negative swap spreads.

Finally, there is a wide range of industry research offering a variety of different reasons 
for the persistent negative 30-year swap spread. One frequently used explanation is the potential credit risk of U.S. Treasuries. ${ }^{2}$ The problem with this argument is that while Treasuries are linked to the credit risk of the U.S., swap rates are linked to the average credit risk of the banking system and a default of the U.S. government would most likely cause defaults in the banking system as well. We investigate the impact of U.S. credit risk (using different measures) on swap spreads and find that it does not significantly affect swap spreads. A second, commonly-offered explanation, is the different funding requirements of swaps and Treasuries. ${ }^{3}$ Long-term Treasury holdings are outright cash positions while engaging in IRS requires only modest capital for initial collateral, typically a small fraction of the Treasury bond principal. Sophisticated investors can use repo agreements to purchase and finance Treasuries, although financing Treasury securities for 30 years would require open repo positions, which need to be rolled over for a long duration. The risk with such a strategy is that the cash lenders may refuse to renew the repo agreement. These considerations are an important limit to the negative swap spreads arbitrage and could explain why there is a limited supply of long-dated swaps. As we explain in more detail below, they are not relevant for pension funds, who, typically, do not use repo transactions.

The roadmap of the paper is as follows. Section 1 of the paper provides some motivating evidence. In Section [II, we present the swap spreads and the underlying drivers for the demand for receiving fixed rates in long-term swaps from pension funds. In Section III, we a simple theory that links pension funds' underfunding and dealers' balance sheet constraints to swap spreads. Section $[\mathrm{IV}$ contains our empirical results for the U.S. Section $\mathrm{V}$ provides additional evidence for Japan and the Neterlands. Section VI concludes. 


\section{Motivating Evidence}

We motivate our model, by documenting a few stylized facts. We first show in Figure 1 that the 30-year swap spread became negative following the bankruptcy of Lehman Brothers, and has been in the negative territory since then.

[Figure 1 about here]

We can see from Figure 1 that the term structure of swap spreads track each other closely until the end of 2007 when long-term swap spreads start decreasing relative to short-term spreads. ${ }^{4}$ Since then, the dynamics of the 30-year swap spreads have decoupled from the dynamics of the other tenures. In the month after the default of Lehman Brothers, highlighted by the first vertical line, the 30-year swap spread drops sharply and turns negative. During that period, there is also a decline in the 10-year swap spread, while swap spreads of shorter maturities increase. Between 2008 and 2014 the 30-year swap spread slowly converges close to 0 and starts decreasing again in 2015. In August 2015, highlighted by the second vertical line, the Libor-Repo spread turns negative, which causes a decrease in swap spreads of all maturities. ${ }^{5}$

We perform a principal components analysis (PCA) of swap spreads before and after September 2008 to see if there is a significant change in the PCs driving the swap spreads after the crisis, relative to the drivers prior to the crisis. We use month-end data for this analysis and the results of our PCA are shown in Table $\mathrm{I}$ next. We present the loadings of each PC before and after September 2008 as well as the proportion of the spreads explained by each PC. ${ }^{6}$

[Table [1] about here] 
Note that prior to the crisis, the first PC explained more than $75 \%$ of the variations in swap spreads for all maturities. The explanatory power of the second PC varied from $23.1 \%$ for 3-year swap spreads to $1.7 \%$ for 10 -year swap spreads. After the crisis, the first PC became even more important in explaining the swap spreads of maturities up to five years, and less so for maturities from seven to thirty years. But the drop in its explanatory power for the 30-year swap spreads is dramatic: it fell from $77.0 \%$ to just $3.1 \%$. In fact, the second PC became the dominant component in explaining the swap spreads for 30-year maturity, in sharp contrast with swap spreads associated with shorter maturities of 10 years of less. Similarly, but to a smaller extent, the explanatory power of the first PC decreased from $78.10 \%$ for the 20 -year swap spread to $24.8 \%$, while the explanatory power of the second PC increased from $17.3 \%$ to $70.2 \%$. Our results in Table @emonstrate that the determinants of 30-year swap spreads underwent a big change after September 2008. This change appears to be unique for swap spreads with maturities above 10-years.

Taken together, Figure 1 and Table[ suggest that the longer-term swap spreads, especially the 30-year swap spreads behaved qualitatively different from the rest of the swap spreads after September 2008. This provides the motivation for both our theory and empirical work. We provide next a possible link between the above evidence and the funding status of defined benefit (DB) pension plans. DB Pension funds have long-dated liabilities and they use longterm interest rate swaps to hedge their duration risk in swap overlay strategies. Adams and Smith (2009) show how interest rate swaps are used by pension funds to manage their duration risk. Furthermore, CGFS (2011) documents that insurance companies and pension funds need to balance asset-liability durations and can do so using swaps. We provide more evidence on the swap usage of pension plans in the next section and document additional anecdotal evidence on their swap usage in Table IA.1 in the internet appendix. 
In theory, a sophisticated investor with full access to repo financing, can buy Treasury bonds and use the repo market to obtain an almost unfunded position. This repo transaction requires an initial funding of approximately $6 \%{ }^{7}$ At the same time, engaging in an IRS could also require an initial margin and regular collateral posting. With the implementation of mandatory central clearing this is becoming more of an issue recently. Nevertheless, as noted earlier, financing a long-term bond for thirty years remains a less practical proposition than merely entering into an interest rate swap. Overall, pension funds find long-term IRS as a simpler vehicle to take leverage than utilizing the repo market for duration hedging purposes. ${ }^{8}$

As noted in a recent Bloomberg article (see Leising, 2013), U.S. pension funds use IRS markets. Further anecdotal evidence of pension funds' demand for IRS and resulting demand pressure is best summarized by the following quote from a recent Bloomberg article: "Pension funds need to hedge long-term liabilities by receiving fixed on long-maturity swap rates. When Lehman dissolved, pension funds found themselves with unmatched hedging needs and then needed to cover these positions in the market with other counterparties. This demand for receiving fixed in the long end drove swap spreads tighter." ${ }^{9}$

We conclude this section by providing some perspective about the size of DB pension funds in the United States. The total size of all private as well as state and local government pension plan assets in the U.S. is about $\$ 8.23$ trillion dollars as of the third quarter of 2015. To make the case that the demand by pension funds to receive fixed in the longterm swap contracts can potentially influence the 30-year swap spread, we next compare the total amount of USD-denominated IRS with 30 or more years to maturity with the total unfunded liabilities of private as well as state and local government employee DB pension plans, which are the focus of this paper. According to the depository trust \& clearing 
corporation (DTCC), the total amount of USD-denominated IRS with 30 or more years to maturity was 1,330 billion USD in September 2015. In comparison, the claims of U.S. DB pension plans on their sponsors, which were 2,044 billion USD in Q3 2015, are huge.

\section{Demand for and Supply of Duration}

In this section we discuss pension funds, their duration matching needs and how underfunding affects their demand for long-dated IRS. We briefly review the implications of regulations such as the pension protection act of 2006 and the diminished incentives to overfund pension plans, due to some tax policy developments. We conclude with an overview of the demand for receiving fixed in long-dated IRS as well as the supply of long-dated IRS.

\section{A. Pension Funds' Duration Matching Needs}

The most important customers in the long end of the swap curve are pension funds and insurance companies, who have a natural demand for receiving fixed for longer tenors. Pension funds have long-term liabilities towards their clients and the Pension Protection Act of 2006 requires them to minimize underfunding by stipulating funding standards and remedial measures to reduce under-funded status. This promotes the incentive to match the duration of their asset portfolios with the duration of these liabilities: Any duration mismatch can produce future shortfalls. Increasing the duration of their asset portfolios could be achieved by receiving fixed in an IRS or by buying bonds with long maturities. Greenwood and Vayanos (2010) provide evidence from the 2004 pension reform in the United Kingdom where pension funds started buying long-dated gilts and more recently Domanski, Shin, and Sushko (2015) show that German insurance companies increased their holdings 
of German long-term bonds significantly over the past years. In line with previous research (see, for instance, Ang et al., 2013 or Ring, 2014, among many others) we document that many U.S. pension funds are underfunded. Using IRS instead of long-dated Treasuries for duration hedging allows pension funds to use their limited funding to invest in more risky assets such as stocks.

To document that pension funds indeed use long-dated IRS to hedge their duration risk, we start by collecting survey data from the Chief Investment Officer magazine, who conducts regular surveys on U.S. pension funds and their investment strategies. ${ }^{10}$ In 2013, 2014, and 2015 they surveyed more than 100 U.S. pension fund managers on their investment strategies. The question most relevant to this paper was whether the plans are using derivatives. A majority of $64.6 \%, 63 \%$, and $70 \%$ of the respondents in 2013,2014 , and 2015 , respectively, stated that they were currently using derivatives. In 2013 and 2014 the respondents provided additional details on their derivatives usage. In 2013 and $201480.9 \%$ and $79 \%$ stated that they were using interest rate swaps, among other derivatives. Furthermore, 25.4\% (29\%) of the respondents in 2013 (2014) stated that they were using derivatives to obtain leverage and $49.2 \%$ (39\%) stated that they are using derivatives for capital/cash efficiency.

Unfortunately, pension funds in the U.S., until recently, are not mandated to report their swap holdings in significant granular detail. A recent working paper by Abad, Aldasoro, Aymanns, D'Errico, Rousová, et al. (2016), quantifies pension funds' swap usage, utilizing a novel dataset of granular swap positions which were reported in November 2015 as mandated by the European Market Infrastructure Reforms (EMIR). Their paper finds that pension funds and insurance companies are net fixed rate receivers in long-dated IRS and that these institutions have a substantial negative price value of a basis point (PV01), consistent with their net positions to receive fixed. Moreover Abad et al. (2016) also notes 
that this negative PV01 can be due to duration hedging. In addition, we summarize several pieces of anecdotal evidence of pension funds' swap usage from Risk Magazine, the New York Times, and quarterly reports of three major U.S. pension plans in Table IA.1 in the internet appendix.

\section{A.1. Pension Funds' Aversion to Over-funding after 1990}

During the period 1986-1990, laws were enacted in the U.S. to discourage "pension reversions" whereby, a pension plan with excess assets can be tapped into by the sponsoring corporation to draw the assets back into the corporation. In 1986, the reversion tax rate was $10 \%$ but by 1990 , this tax rate had increased to $50 \%$. In addition, the sponsoring firm was also required to pay corporate income tax on reversions. These changes in tax policies meant that the U.S. corporations have dramatically lower incentives to overfund their pension plans since 1990 than was the case before. This is important to note because pension plans were generally not significantly overfunded before the onset of the credit crisis of 2008 which made them vulnerable to becoming underfunded should there be a big correction in equity markets or a protracted fall in discount rates, which can cause the pension liabilities to increase (both these developments occurred after the credit crisis of 2008)

Once the plans become underfunded and the rates fall (as was the case after 2008), the plan sponsors are faced with two objectives: first to match the duration of assets with liabilities to avoid future underfunding due to market movements, and second to find assets which can provide sufficiently high returns to get out of their underfunded status. This is the context in which the long-term swaps play a role: they enable the sponsors to match duration without setting aside any explicit funding and the sponsor can then use the limited funding to invest in riskier assets in the hope of earning higher returns. 


\section{B. The Supply of Long-Dated Swaps}

\section{B.1. Investors}

In general, investors could either have a demand for receiving fixed in an IRS or for paying fixed in an IRS and may use IRS for speculative and hedging purposes. In any case, the demand for IRS can depend on the level and the slope of the yield curve. The level of the yield curve matters, for instance, for agencies issuing Mortgage-Backed Securities (MBS). Agencies aim to balance the duration of their assets and liabilities. When interest rates fall, mortgage borrowers tend to execute their prepayment right, thereby lowering the duration of the agencies' mortgage portfolio. Hence, agencies want to receive fixed in an IRS to hedge this mortgage prepayment risk (see Hanson, 2014). ${ }^{11}$ The slope of the yield curve may also matter for non-financial firms. According to Faulkender (2005), these firms tend to use IRS

mostly for speculation, preferring to pay floating when the yield curve is steep. Faulkender (2005) also finds that firms tend to prefer paying fixed when macro-economic conditions worsen. Overall, these papers show that there could be demand and supply effects from other investors. However, as these examples suggest, it is hard to conclude that non-financial firms have a large demand for long-dated IRS with a maturity of 30 years. ${ }^{12}$ This is also consistent with the data presented in Abad et al. (2016). It is therefore reasonable to conclude that the demand for receiving fixed in long-dated IRS by pension funds is not offset by supply from other institutions and has to be met largely by derivatives broker-dealers.

\section{B.2. Broker-Dealers}

A broker-dealer paying fixed in a long-dated IRS, thereby taking the opposite position than a pension fund would generally aim to hedge the interest-rate risk of his position. 
He can either do so by finding another counterparty willing to pay fixed or by following a hedging strategy where he purchases a 30-year treasury bond financed with a short-term repo transaction in order to hedge the duration risk. This transaction, combined with paying fixed in the IRS would result in the dealer paying the swap spread and receiving the difference between Libor rate and swap rate. ${ }^{13}$ We discussed above that finding a counterparty willing to pay fixed in long-dated swaps is difficult and now highlight two issues with this hedging strategy that limit the supply of long-dated IRS.

The first issue has to do with margin requirements. Financing the purchase of the longdated government bonds with short-term borrowing is subject to the risk of increasing margin requirements. For instance, Krishnamurthy (2010) documents that haircuts for longer-dated government bonds increased from $5 \%$ to $6 \%$ during the crisis. The haircut for 30 -year bonds conceivably increased even more. Furthermore, Musto, Nini, and Schwarz (2014) document that the amount of repo transactions decreased sharply during the financial crisis. One possible reason for this observation is that the supply of repo financing deteriorated and hence borrowing at repo was not always possible, especially for long-term swaps. Hence, the arbitrage strategy is subject to a severe funding risk. Furthermore, engaging in an IRS requires an initial margin as well. This margin requirement increased after the financial crisis. Hence the dealer may be forced to offer a lower fixed rate on long-term swaps.

The second issue is a standard limits of arbitrage argument. As pointed out by Shleifer and Vishny (1997), Liu and Longstaff (2004), and many others, arbitrage opportunities are subject to the risk that the mispricing increases before it vanishes, thereby forcing the arbitrageur out of his position at a loss. With negative 30-year swap spreads arbitrage, we know that the mispricing vanishes after 30 years, but we do not know whether it will vanish within a much shorter and practical horizon. To benefit from negative swap spreads arbitrage 
a high amount of leverage is required and arbitraging negative swap spreads can therefore be seen as a case of "picking up Nickels in front of a steamroller" (Duarte, Longstaff, and $\mathrm{Yu}, 2007) .{ }^{14}$

\section{Illustrative Theory}

In this section, we illustrate the link between pension funds' underfunding and swap spreads. We start by deriving the main intuition in a model-free setting and then formalize our results in a simple model. Our analysis consists of two parts. First, we show that underfunded pension plans optimally take a position in long-dated interest rate swaps, receiving fixed and paying floating. Second, to derive the equilibrium swap spread, we assume that derivatives dealers with balance sheet constraints require a compensation in the form of negative swap spreads for providing the IRS to the pension funds.

\section{A. Swap Spreads and Balance Sheet Constraints}

We make the following four simplifying assumptions in our analysis. First, we focus on the trade-off between holding bonds and using swaps. That is, we take the pension fund's other investments as exogenously given and assume no contributions by the plan sponsor. Second, we assume that there is no default risk in the model. In particular, we set the Libor-Repo spread equal to zero, which means that the fair swap spread in our model would be equal to zero. Third, we focus our analysis on perpetual bonds and perpetual swaps and do not consider shorter maturities. Finally, we focus our considerations on market clearing in the IRS market only and take bond prices as exogenously given.

The main difference between bonds and swaps is that bonds require an initial cash outlay 
while swaps typically have a fair value of zero at issuance. Let $P$ denote the price of a perpetual bond paying one dollar per unit time. An IRS with the same maturity pays a fixed rate $c$ per unit time, and requires a floating payment of $r_{s}$ at each instant $s$, where $r_{s}$ is the instantaneous risk-free rate. From the perspective of the fixed rate receiver, the present value of the swap for any $c$ is then given as:

$$
P V(S)=c P-1 .
$$

At the time the swap is initiated, the fixed rate will be chosen such that the swap value is zero, which implies a swap rate of $c=1 / P$. The present value in Equation (1) is the value of the swap in the absence of an intermediation cost. Below, we introduce the negative swap spread as an intermediation cost, paid by the fixed receiver. This intermediation cost will clear the swap market.

\section{A.1. Demand by Pension Funds}

The pension fund has a perpertual liability that requires a payment of $L$ dollars per unit time. Hence, the present value of the fund's liabilities is given as $L P$. We denote the total value of the fund's assets by $A$. The focus of our analysis is on underfunded pension plans wherein the amount of underfunding, $F:=L P-A>0$, is positive. In an attempt to minimize its underfunding and to hedge the interest rate risk of its liabilities, the pension fund chooses its investments in bonds and swaps. To that end, the fund can first use the

existing assets $A$ to buy $\frac{A}{P}$ bonds. After having allocated its entire available funding to bonds, the fund can meet the rest of the pension obligations in two different ways. First, the fund can enter into a number, $n$, of swaps such that $n c=L-A / P$. Second, the fund 
can take a short position in the risk-free asset, thereby taking direct leverage, to purchase $L-A / P$ more bonds. This latter option is only for illustrative purposes because pension funds typically do not use direct leverage.

Panel A of Table II shows the cashflows from using $n$ IRS in a perfect market where swap spreads are equal to zero. As we can see from the table, the fixed cashflows from the IRS position together with the cashflows from purchasing $\frac{A}{P}$ bonds offset the cashflows $L$ from the obligation. In addition, Panel A shows that, if the fund can freely borrow money at the risk-free rate, the swap strategy is equivalent to borrowing money and purchasing the perpetual bond. In practice, however, pension funds face a significant cost for using direct leverage. We denote that cost by $\phi$ and illustrate the cashflows from borrowing money in order to purchase bonds in Panel B of Table II. Taken together, Panels A and B illustrate that, as long as the cost incurred by the negative swap spread is smaller than the cost of direct leverage $\phi$, the pension fund optimally uses swaps.

\section{[Table II about here]}

\section{A.2. Supply by Derivatives Dealers and Equilibrium}

Pension funds normally do not take repo positions, and the strategy described in Panel B is therefore more relevant for swap dealers. As discussed in Section II.B, the demand for long-dated IRS is typically met by derivatives dealers who pay the fixed rate and receive the variable payments. In order to hedge their positions, the dealers need to borrow money to purchase bonds, thereby engaging in a strategy resembling the one in Panel B of Table II. The difference between pension funds and derivatives dealers is that the dealers have better access to repo markets and hence to direct leverage. In addition, swap dealers face 
many counterparties with whom they can eventually offset some of their swap positions. The dealers are therefore able to replicate a fixed payer position in an IRS at a lower cost than pension funds. We assume that the dealers charge an intermediation fee $-\delta$, which can be interpreted as negative swap spread, for providing the IRS to pension funds. This fee, required by swap dealers, is lower than the pension funds cost of replicating the swap. Nevertheless, the balance sheet constraints of the dealer will determine their cost of supplying the IRS and hence the swap spread $\delta$.

\section{B. A Simple Model}

We now incorporate the above arguments in a simple model. The details of the model are described in Appendix B, and we present the main features and the results here. To that end, we define $\mu_{P}:=\mathbb{E}[d P / P]$ and $\sigma_{P}^{2}:=\operatorname{var}(d P / P)$ as the mean and variance of the relative changes of the consol bond price introduced above.

\section{B.1. Demand by Pension Funds}

As before, we let $F=L P-A$ denote the pension funds underfunding and focus on underfunded pension funds, that is funds with $F>0$. To keep the model tractable, we assume a static setup in which the pension fund is minimizing its future underfunding with risk aversion $\gamma$. Proposition 1 formalizes the intuition from the previous section.

PROPOSITION 1: Assume that $-\delta<\phi$ and $-\delta \leq\left(\mu_{P}-r\right)+\frac{\gamma}{2} F \sigma_{P}^{2}$. Then, the pension fund optimally invests $m^{*}=A / P$ in bonds and its optimal allocation to swaps is given as:

$$
n^{*}=F+\frac{\delta}{\gamma \sigma_{P}^{2}}+\frac{\mu_{P}-r}{\gamma \sigma_{P}^{2}}
$$


The proof of Proposition 1 can be found in Appendix A. The first condition, $-\delta<\phi$, requires that the cost of using swaps is smaller than the cost implied by financing in repo markets. The second condition, $-\delta \leq\left(\mu_{P}-r\right)+\frac{\gamma}{2} F \sigma_{P}^{2}$, ensures that the pension fund is better off by using swaps than by simply investing $m=A / P$ in bonds. As we will see below, this condition is typically satisfied. The interpretation of Equation (2) straightforward. First, the more underfunded the pension fund is, the more swaps it requires to hedge its liabilities. Second, as the swap spread $\delta$ becomes more negative, the fund's demand for IRS decreases. Finally, a risk premium associated with buying bonds, that is $\mu_{P}>r$, increases the fund's demand for IRS.

\section{B.2. Supply by Derivatives Dealers and Equilibrium}

On the supply side of long-dated IRS, we assume that derivatives dealers decide on the amount $s$ of long-dated swaps that they supply, by maximizing their expected profits. We take a stylized view on the dealers' balance sheet, only focusing on their swap supply. Appendix B contains a description of their optimization problem. The swap dealer has a risk-aversion coefficient, $a$, which reflects their aversion to interest rate risk.

PROPOSITION 2: Let $a<\gamma$. Then, the equilibrium swap spread is given as:

$$
-\delta=F\left(\frac{a \gamma \sigma_{P}^{2}}{\gamma+a}\right)+\left[\mu_{P}-r\right]\left(\frac{a}{\gamma+a}\right) .
$$

The proof of Proposition 2 can be found in Appendix A. As we can see from Equation (3), the equilibrium swap spread decreases as the pension fund's underfunding $F$ increases. Moreover, the proposition shows that, if dealer banks face tighter constraints, represented by a higher value of $a$, the swap spread decreases and the effect of pension fund's underfunding 
on swap spreads becomes stronger. In the Internet Appendix, we numerically illustrate the negative swap spreads implications of the model with the mean-reverting model of Vasicek (1977).

\section{Empirical Analysis for U.S. Swap Spreads}

This section consists of five parts. First, we describe our approach to measuring pension fund underfunding and constructing an aggregate measure for the underfunded ratio $(U F R)$ of U.S. pension funds. We construct similar measures for Japan and the Netherlands in Section V. Second, we illustrate the link between UFR and 30-year swap spreads and document that 30-year swap spreads are more affected by $U F R$, when pension funds on the aggregate, are underfunded. Third, we run OLS regressions to test the relationship between the 30-year swap spread and $U F R$, controlling for a number of factors. Fourth, we address the possible concern that the level of the yield curve can drive both the swap spread and $U F R$ in a 2-stage least squares regression, where we use stock returns as an instrument. Finally, we conclude this section with several robustness tests.

\section{A. Measuring Pension Fund Underfunding}

To test our hypotheses, we first construct a measure of pension fund underfunding. We obtain quarterly data on two types of defined benefit (DB) pension plans, private as well as public local government pension plans, from the financial accounts of the U.S. (former flow of funds) tables L.118b and L.120b. We exclude defined contribution pension plans since they cannot become underfunded and also exclude public federal DB pension plans

since they are only allowed to invest in government bonds. We first note that the overall 
size of the pension funds' balance sheet is 8,235 billion U.S. dollar (as of Q3 2015), thereby capturing approximately $45 \%$ of the total assets held by all U.S. pension funds. Furthermore, comparing the size of the pension funds' balance sheet to the size of the U.S. broker-dealers' balance sheet shows that it is approximately 2.5 times as large.

\section{[Table III] about here]}

Table III shows the aggregate pension fund balance sheet for the third quarter of 2015. As we can see from the table, the liabilities of these pension funds consist only of pension entitlements. On the asset side, there are three major positions. First, corporate equities, which make up more than one third of the balance sheet. Second, claims of pension fund on sponsor, which account for almost one quarter of the pension funds assets. As we describe below, these claims on sponsor are our main proxy for underfunding. ${ }^{15}$. Third, debt securities, which consist mainly of fixed-rate securities, like corporate bonds.

We use claims of pension funds on sponsors as our measure of pension funds' underfunding ratio $(U F R) . U F R$ in quarter $t$ is computed as:

$$
U F R_{t}=\frac{\text { Private DB claims on } \text { Sponsor }_{t}+\text { Public DB claims on } \text { Sponsor }_{t}}{\text { Private DB total financial } \text { assets }_{t}+\text { Public DB total financial assets }} .
$$

The claims of a pension fund on its sponsor represent the difference between the fund's actuarial liabilities and its assets. It reflects the amount of underfunding or overfunding of the plans. These claims (which can be positive or negative) are treated as an asset of the pension funds sector and a liability of the sponsors of the plans. ${ }^{16}$ If claims of pension fund on sponsor is positive, pension funds are underfunded. Since our hypothesis is that $U F R$ has a more significant impact on swap spreads if it is positive, we introduce the notation $U F R_{t}^{+}:=\max \left(U F R_{t}, 0\right)$ and $U F R_{t}^{-}:=\min \left(U F R_{t}, 0\right)$ for the positive and negative 
part of the underfunding ratio respectively. Since we are using changes in $U F R$ in our regression analysis, we also introduce the notation $\Delta U F R_{t}^{+}:=\left(U F R_{t}-U F R_{t-1}\right) \mathbb{1}_{\left\{U F R_{t}>0\right\}}$ and $\Delta U F R_{t}^{-}:=\left(U F R_{t}-U F R_{t-1}\right) \mathbb{1}_{\left\{U F R_{t} \leq 0\right\}}$. Note that the way we define $\Delta U F R_{t}^{+}$means that the measure includes a change from fully funded to underfunded periods but not from underfunded to fully-funded periods (this change is included in $\Delta U F R_{t}^{-}$).

\section{B. Swap Spreads in Different Underfunding Regimes}

It should be noted that for the end of quarter $t$, the Fed's financial accounts of the U.S. report the pension sponsors' funding status resulting from events during the end-quarter $t-1$ to end-quarter $t$. This is reported roughly 2 weeks after end of quarter $t$. The swap spreads that we use in the paper are calculated precisely at the end of quarter $t$. In this sense

our measure of funding status for quarter end $t, U F R_{t}$, which is based on the information from end-quarter $t-1$ to end-quarter $t$ is effectively a lagged measure relative to the time at which the swap spreads are collected.

Using the UFR measure constructed above, we provide some preliminary evidence on the proposition that the demand by a significant subset of pension sponsors to receive fixed in long-term swaps has an effect on long-term swap spreads.

[Figure 2 about here]

The top panel of Figure 2 shows a scatter plot of the 30-year swap spreads in basis points against our measure of aggregate funding status, $U F R_{t}$, and gives a first overview of the results. The time period is between Q2 1994 and Q4 2015. The swap spreads are quarter-end observations and we distinguish between the negative part (solid dots) and positive part (circles) of the $U F R$, fitting a linear model with a different slope coefficient in 
the two regimes. The dashed lines indicate $95 \%$ confidence intervals. As we can see from the top panel of Figure 2, the level of the swap spreads is negatively related to the $U F R$ for both funded and underfunded regions. In line with our theory, the slope coefficient is more negative in periods when pension funds are underfunded. The lower panel of Figure 2 shows the time series plot of the same variables, illustrating that both variables are relatively volatile without an obvious trend component. The grey shaded areas indicate periods where pension funds are fully funded or over-funded. The U.S. Economy was generating a surplus during the end of this (shaded) period, with a drop in the supply of long-term government bonds, which might have partially accounted for the increase in swap spreads. The stock market boom during this period could have partially accounted for the over-funded status of the pension plans.

The evidence presented in this section helps to motivate why the funding status of pension plans, as suggested by our theory, may be a channel that could be at work in driving the swap spreads down to negative levels. We next use regression analysis to further explore this channel.

\section{Regression Analysis}

To shed additional light on the relationship between $U F R$ and swap spreads we next run a regression analysis of changes in 30-year swap spreads on changes in $U F R .{ }^{17}$ Motivated by the hedging strategy described in Section II.B.2, we control for the change in the difference between the 3-months Libor rate and 3-month general collateral repo rate $\left(\Delta L R \operatorname{spread}_{t}\right)$ in all regression specifications. Panels (1) and (2) of Table IV show that, without additional control variables, pension fund underfunding is a significant explanatory variable for 30-year swap spreads. 
[Table $[\mathrm{IV}$ about here]

Panel (1) shows that $U F R$ for the entire sample period is statistically significant at a $1 \%$ level with a coefficient of -1.08 ( $t$-statistic of -2.94$)$. More importantly and in line with our theory, panel (2) shows that $U F R$ is even more significant when only considering underfunded regimes and insignificant when pension funds, on the aggregate, are fully funded. For underfunded periods, $U F R$ is statistically significant at a $1 \%$ level with a coefficient of -1.32 ( $t$-statistic of -3.46$)$ and for funded periods $U F R$ is insignificant with a coefficient of -0.55 ( $t$-statistic of -0.78$)$. Note that a coefficient of -1 indicates that swap spreads fall by one basis point when pension fund underfunding increases by $1 \%$.

We next check whether our results are robust to controlling for other factors that are likely to affect swap spreads. We start by adding four control variables, the U.S. debt-toGDP ratio as a proxy for the "convenience yield" of U.S. Treasuries (Krishnamurthy and Vissing-Jorgensen, 2012), the average Moody's expected default frequency (EDF) of the 14 largest derivatives-dealing banks, the implied volatility in U.S. Treasuries as proxied by the Move index, and a term factor, measuring the slope of the yield curve. These variables (as well as all other data used in our analysis) are described in more detail in Appendix B. The results of these regressions are reported in Panels (3) and (4) of Table IV.

As we can see from the table, Debt-to-GDP is insignificant but with the expected sign: An increase in Debt-to-GDP lowers the convenience yield of treasuries, thereby lowering the swap spread. $\triangle E D F_{t}$ is statistically significant and an increase in derivatives dealers' expected default frequency lowers the swap spread, indicating that, as dealers become more constrained, swap spreads decrease. $\triangle M o v e_{t}$ and $\triangle T E R M_{t}$ are both significant and an increase in uncertainty, as captured by Move, increases the swap spread. Most importantly, as we can see from Panels (3) and (4) of Table IV, controlling for these variables leads to a 
small drop in the statistical and economic significance of $U F R$, but leaves our main result unchanged. Panel (3) shows that UFR for the full sample period is still significant at a $5 \%$ level with a coefficient of -0.96 ( $t$-statistic of -2.19$)$. More importantly, Panel (4) shows that $U F R$ during times of underfunding is still statistically significant at a $1 \%$ level with a coefficient of -1.27 ( $t$-statistic of -3.18).

In panels (5) and (6) we add three more sets of control variables to check whether our results remain robust to including more potential drivers of swap spreads. The first set of control variables consists of the smoothed U.S. recession probabilities, as estimated by Chauvet and Piger (2008), and two versions of the economic policy uncertainty (EPU) index, constructed by Baker, Bloom, and Davis (2016) - uncertainty about the U.S. debt ceiling and uncertainty about government spending. These variables can be viewed as proxies for credit risk of the U.S. and could therefore affect swap spreads through a higher treasury yield. The second set of control variables include the mortgage refinancing rate and the amount of U.S. agency MBS outstanding. ${ }^{18}$ These variables proxy for the impact of MBS duration hedging on swap spreads. The last set of controls consists of the level of the 30-year treasury yield, the broker-dealer leverage factor by Adrian, Etula, and Muir (2014), the VIX index, and the 10-year on-the-run off-the-run spread, which could, in theory, also impact swap spreads. Out of all these additional control variables, only the version of the EPU index that captures uncertainty about the debt ceiling is statistically significant. We do not report the coefficient estimates for the additional insignificant variables for brevity and note that adding these additional control variables only leads to a minor increase in the explanatory power of our model (compared to specifications (3) and (4)). More importantly, adding these controls leads to a minor drop in the statistical and economical significance of $\Delta U F R_{t}^{+}$, but leaves our main results intact. Interestingly, the coefficient on $\log \left(E P U_{t}^{\text {DebtCeil }}\right)$ is positive, 
indicating that concerns about the U.S. debt ceiling tend to widen swap spreads.

As a next step, we check whether $U F R$ is a significant explanatory variable for swap spreads with shorter maturities. To that end, we regress changes in the 2-year, 5-year, 10-year, and 30-year swap spread on the positive and negative part of changes in $U F R$, controlling for changes in the Libor-repo spread. ${ }^{19}$ The results of this regression are exhibited

in Table V. In line with our theory, $U F R^{+}$is only significant for the 30-year swap spread and insignificant for swap spreads with shorter maturities. We note that, in line with the hedging argument from Section II.B.2, the Libor-repo spread is a significant explanatory variable for swap spreads with shorter maturities (2-year and 5-year).

\section{[Table V] about here]}

In addition, we note that $U F R$ is also a significant explanatory variable for 20-year swap spreads and that the results for 20-year swap spreads are qualitatively similar to those for 30-year swap spreads, reported above. However, since the 20-year tenor is not a common maturity for IRS and because, unlike the other tenors used in this section, the 20-year swap spread needs to be computed using off-the-run bond yields, we relegate the discussion of 20-year swap spreads to Internet Appendix A.

\section{Two-Stage Least Squares Regression Results}

One concern about using $U F R$ as an explanatory variable for swap spreads is that similar factors can affect both variables. For example, a decrease in the level of the yield curve can simultaneously affect swap spreads and the level of pension funds' underfunding (which would increase because the present value of the funds' liabilities is computed using long-term interest rates). To mitigate these concerns, we next run a 2-stage least squares regression. 
In a first stage, we regress $\Delta U F R_{t}$ on U.S. stock returns proxied by the excess return on the CRSP value-weighted portfolio. In panels (2), (4), and (6) we drop fully funded periods and only regress $\Delta U F R_{t}^{+}$on stock returns. Stock returns affect $U F R$ since pension funds are heavily invested in corporate equity (almost half their assets are invested in corporate equity according to Table III) and therefore decreasing stock returns increase UFR. At the same time, there is no obvious connection between the 30-year swap spread and stock returns.

\section{[Table VI about here]}

We therefore argue that the exclusion restriction is fulfilled. Furthermore, the results from a weak instrument test give a $p$-value far below $0.1 \%$ for all six regression specifications, suggesting that stock returns are not a weak instrument. In addition, the results from a WuHausman test give a $p$-value above 0.17 (ranging from 0.751 for specification (1) to 0.170 for specification (6)) for all six specifications. Hence, we cannot reject the over-identifying restrictions.

Table VI shows the results of the second stage, where we use the projected $U F R$ as explanatory variable. Overall the results from the second stage are similar to those from the OLS regression discussed before. The projected $U F R$ is significant at a $1 \%$ level and decreases in significance as we add controls. More importantly, the projected underfunded ratio in regimes when pension funds are underfunded is even more significant ( $t$-statistic of -3.30 without controls) and remains significant even after adding our four main control variables $(t$-statistic of -2.75$)$. 


\section{E. Robustness Tests}

To test the robustness of our results, we first note that we view our regression specification (4) in Table IV as our main result and therefore focus on testing different variations of this specification. We start by adding two different control variables to our analysis: CDS premiums on the U.S. treasury and U.S. corporate bond issuance. ${ }^{20}$ We omit these variables in our main tests because they are not available for the entire sample period and therefore lower the total number of available observations. Moreover, as noted by Klingler and Lando (2016), CDS premiums of safe countries do not necessarily reflect credit risk and can be affected by other variables, such as dealer banks' financial constraints and regulatory variables. We therefore view the control variables in Panels (5) and (6) of Table [V] as better suited for testing the impact of U.S. credit risk on swap spreads.

\section{[Table VII about here]}

As we can see from Panel (1) of Table VII, controlling for U.S. CDS premiums lowers the significance of $\triangle U F R_{t}^{+}$but the CDS premiums themselves are not a significant explanatory variable. Panel (2) of Table VII shows that controlling for U.S. corporate bond issuance does not lower the significance of $\Delta U F R_{t}^{+}$and that corporate bond issuance is an insignificant explanatory variable for 30-year swap spreads, but tends to lower the swap spread.

Next, we investigate the effect of $U F R$ on swap spreads in different sample periods. One potential concern could be that a significant spike in $U F R$ coincided with a significant drop in swap spreads when Lehman Brothers defaulted and that the impact of $U F R$ on swap spreads could therefore purely be a post-crisis effect. To address this concern, we add a dummy slope variable that is equal to zero before Q3 2008 and equal to $\Delta U F R_{t}$ from Q3 2008 on. As we can see from Panel (3) of Table VII, this dummy slope variable is not 
statistically significant. We also investigate the impact of $U F R$ on swap spreads in the subsequent years of the default of Lehman Brothers. To that end, we add three different dummy slope variables: The first one is equal to $\Delta U F R_{t}$ from Q3 2008 to Q2 2009 and zero in all other quarters. Similarly, the second and the third dummy slope variables are equal to $\Delta U F R_{t}$ from Q3 2009 to Q2 2010 and from Q3 2010 to Q2 2011, respectively, and zero in all other quarters. As we can see from the table, the effect of $U F R$ on swap spreads is almost twice as large during the year after the default of Lehman Brothers. This is in line with our theory that the demand for duration by underfunded pension plans in combination with constrained derivatives dealers drove swap spreads negative. Moreover, $U F R$ is still a significant explanatory variable for swap spreads over the entire period and the dummy slope variables for the years after the default of Lehman Brothers are not statistically significant.

Finally, we note that it would be ideal to only aggregate the positive part of pension funds' claims on their sponsors instead of simply using the aggregated claims across all pension funds. Unfortunately, these, more granular, data are not available in the financial accounts of the U.S. tables. To test whether this heterogeneity could potentially affect our results, we modify our $U F R$ measure and define

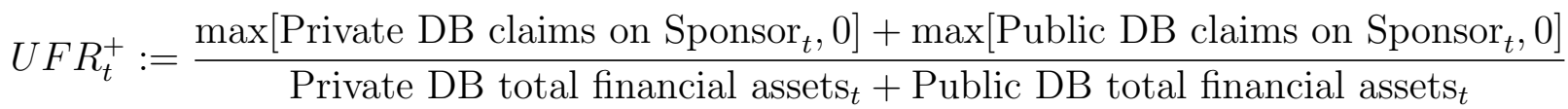

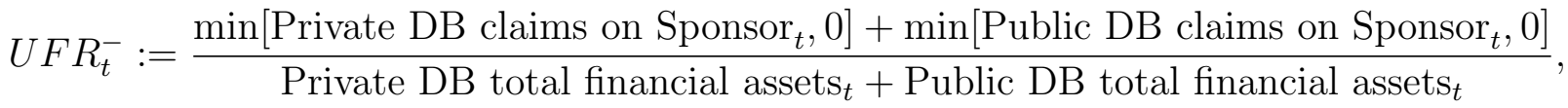

taking the heterogeneity between private and public plans into account. As we can see from Panel (5) of Table VII, using this alternative version of the UFR measure leads to almost identical results as our original $U F R$ measure. Moreover, we also experimented with defining 
underfunded regimes at different cut-off points, such as $-10 \%,-5 \%, 5 \%$, and $10 \%$. For all four alternative cut-off points $\Delta U F R_{t}^{+}$was a significant explanatory variable for 30-year swap spreads while $\Delta U F R_{t}^{-}$was insignificant.

\section{International Evidence}

Because neither negative swap spreads nor large-scale duration hedging by pension funds are purely a U.S. phenomenon, we next investigate the effects of pension funds' underfunding in different regions. ${ }^{21}$ According to a recent study by the OECD, the world's five largest autonomous pension fund systems are located in the U.S., the U.K., Australia, Japan, and the Netherlands, with all five systems managing more than one trillion U.S. dollars of investments (see (OECD, 2016)). Therefore, we next study the effects of pension fund underfunding in two of these regions: Japan and the Netherlands. ${ }^{22}$

\section{A. The Data}

We obtain Japanese government bond yields and swap rates from the Bloomberg system. In contrast to the U.S., where the floating rate is paid quarterly, in Japan, a fixed rate is exchanged against a semi-annual floating payment. We then obtain private DB pension funds' claims on their sponsor as well as private DB pension funds' total financial assets from Japan's flow of funds accounts. We exclude public pension funds because, for this subcategory, the flow of funds accounts do not provide a split between DB and DC funds. Hence our measure of underfunding for Japan is constructed as:

$$
U F R_{t}^{J a p}=\frac{\text { Private DB claims on } \text { sponsor }_{t}}{\text { Private DB total financial assets } t} .
$$


Quarterly data on the funding status of DB pension funds are available from Q1 2005. Panel A of Table VIII provides summary statistics for $U F R_{t}^{J a p}$ as well as 30-year swap spreads. As we can see from the table, Japanese pension funds have been underfunded during the entire sample period. Moreover, the maximum level of $U F R_{t}^{J a p}$ exceeds the maximum level of $U F R_{t}$ in the U.S. by almost 10\%. The higher underfunded ratio of Japanese pension funds relative to the U.S. is not surprising, given that Japanese pension funds have been dealing with decreasing interest rates and falling stock prices for much longer than U.S. pension funds. Similarly to the U.S., Japanese pension funds try to avoid forcing their sponsors to cover losses and the usage of swaps is explicitly permitted for these funds.

\section{[Table VIII about here]}

When investigating the impact of pension funds' underfunding on swap spreads for the Netherlands, we define swap spreads as the difference between the Euribor swap rate and the yield of German government bonds in our main analysis and use swap spreads relative to the yield of Dutch government bonds as a robustness check. We obtain swap rates and government bond yields from the Bloomberg system. Data for the funding status of Dutch DB pension funds are available on the DNB website, which provides data for "Liquid assets at funds' risk" and "Estimated technical provision at funds' risk" from Q1 2007 on. According to the Dutch pension fund regulation, a pension fund is underfunded if the ratio between the two variables drops below $105 \%$. In that case, a plan needs to provide a proposal of how to become fully funded in the future to the Dutch supervisory authority and needs to lower the

overall risk of its portfolio, which is mainly done by reducing interest rate risk. ${ }^{23}$ Based on these arguments, we first calculate the funding gap of Dutch pension funds as the difference between 1.05 times the estimated technical provision at funds' risk and liquid assets at funds' 
risk. We then construct $U F R_{t}^{\text {Neth }}$ as follows:

$$
U F R_{t}^{\text {Neth }}=\frac{\text { Funding gap }}{\text { Liquid assets at funds' risk }}
$$

Finally, as we did for the U.S., we split the measure into a positive part, which corresponds to times when pension funds are not underfunded and negative part that captures pension funds' underfunding. Panel B of Table VIII provides summary statistics for the Dutch $U F R$ measure as well as 30-year swap spreads relative to German government bonds and relative to Dutch government bonds. As we can see from the table, Dutch pension funds are rarely underfunded with a total of 12 underfunding observations. ${ }^{24}$

\section{B. Results}

We next test the relationship between swap spreads and $U F R_{t}$ for Japan and the Netherlands. To that end, we regress changes of 2-year, 5-year, 10-year, and 30-year swap spreads on the $\Delta U F R_{t}^{+}$and $\Delta U F R_{t}^{-}$. In Japan, pension funds have been underfunded for the entire sample period and we therefore $\operatorname{drop} \Delta U F R_{t}^{-}$from the regression. Furthermore, we add the 6-month Libor-Repo spread as a control variable for Japan and do not control for changes in the Libor-Repo spread in Europe due to limited data availability.

As we can see from Panel A of Table IX, $\Delta U F R_{t}^{+}$is a significant explanatory variable for 10-year and 30-year Japanese swap spreads but not for swap spreads with shorter maturities. Both the statistical and economic significance of $\Delta U F R_{t}^{+}$are higher for 30-year swap spreads than for 10-year swap spreads. Note that $\Delta U F R_{t}^{+}$is an even more significant explanatory variable for Japanese 30-year swap spreads than for the U.S. Hence, we provide additional results for Japan in the internet appendix. Analogous to the results for Japan, Panel B of 
Table IX shows that, for the Netherlands, $\Delta U F R_{t}^{+}$is a significant explanatory variable for 30-year swap spreads (measured relative to German and Dutch government bond yields) and insignificant for swap spreads with shorter maturities.

[Table IX about here]

\section{Conclusion}

We provide a novel explanation of persistent negative 30-year swap spreads, which is based on the funding status of DB pension plans and the swap dealers' balance sheet constraints. Specifically, we argue that under-funded pension plans prefer to meet the duration needs arising from their unfunded pension liabilities through receiving fixed payments in 30-year interest rate swaps, instead of using levered positions in bonds. Swap dealers, who face balance-sheet constraints, require a compensation in the form of negative swap spreads to meet this demand. We present empirical evidence, which supports the view that the underfunded status of DB pension plans has a significant explanatory power for 30-year swap spreads, even after controlling for several other drivers of swap spreads, commonly used in the swap literature. Moreover, we show that the funding status does not have any explanatory power for swap spreads associated with shorter maturities between 2 and 10 years. We present fairly consistent empirical evidence from the United States, Japan and Netherlands. 


\section{Appendix A. Model and Proofs}

According to Equation (1), the dynamics of the swap PV are given as $d P V(S)=c d P$. To derive a simple expression for the negative swap spread, we take the dynamics of the consol bond as exogenously given and focus on market clearing in the swap market only. As in our general analysis, we model the swap spread as a flow cost $\delta \leq 0$ that the fixed receiver of the swap pays in addition to the risk-free rate.

To keep the model tractable, we assume a static setup in which the pension fund is minimizing its future underfunding with risk aversion $\gamma:{ }^{25}$

$$
\min _{m, n}\left[\mathbb{E}[F]+\frac{\gamma}{2} \operatorname{Var}(F)\right]
$$

The dynamics of $F$ are given as:

$$
d F=(L-m-n c) d P+(r-\delta) d t+(r+\phi)(m P+n(c P-1)-A) d t
$$

where we implicitly assume $m P+n(c P-1)-A \geq 0$ (otherwise the fund would invest money at the risk-free rate and receive a return $r+\phi$ instead of $r$ ).

The swap dealers decide on the swap supply based on the following mean-variance optimization problem:

$$
\max _{s}\left[r W-s \delta-\frac{a}{2}\left(s^{2} \sigma^{2}\right)\right]
$$

where we assume that dealers associate no risk premium to trading swaps. The interpretation of the risk-aversion $a$ is that dealers face balance sheet constraints and even a hedged position in an IRS requires balance sheet. In this model setup, the amount of balance sheet consumed 
by a new swap position is proportional to the variance of the swap's mark-to-market value. The coefficient $a$ can therefore be interpreted as the tightness of the dealers' balance sheet

constraint. For $a=0$, the dealer is unconstrained and would supply swaps at the fair swap spread $\delta=0$. Proposition 2 characterizes the equilibrium swap spread in our setting.

Equilibrium in our model is defined as a situation where pension funds solve problem (A1), derivatives dealers solve problem (A2), and the interest rate swap market clears.

\section{Proof of Proposition 1}

Plugging $\mu_{P}$ and $\sigma_{P}$ into Equation (A1), the fund's optimization problem simplifies to:

$$
\min _{m, n}\left[(L P-m P-n) \mu_{P}+\frac{\gamma}{2}(L P-m P-n)^{2} \sigma_{P}^{2}+[n(r-\delta)+(r+\phi)(m P-A)]\right],
$$

where the first two terms are the mean and the variance of the underfunding and the last term represents the sum of the costs of using swaps and the cost of using direct leverage. Taking the FOC of Equation A3 gives:

$$
\begin{aligned}
& \frac{\partial}{\partial m}:-P \mu_{P}+(r+\phi) P-\gamma P(L P-m P-n) \sigma_{P}^{2} \stackrel{!}{=} 0 \\
& \frac{\partial}{\partial n}:-\mu_{P}-(\delta-r)-\gamma(L P-m P-n) \sigma_{P}^{2} \stackrel{!}{=} 0
\end{aligned}
$$

Because swaps and bonds are perfectly correlated, we start by considering the following three corner solutions. First, if the pension fund only uses consols and pays the short-selling cost $\phi$, then his optimal allocation to consols is given as:

$$
m P=L P+\frac{\mu_{P}-r}{\gamma \sigma_{P}^{2}}-\frac{\phi}{\gamma \sigma_{P}^{2}}
$$


and the value function is:

$$
(r+\phi) F-\frac{1}{2} \frac{\left(\mu_{P}-(r+\phi)\right)^{2}}{\gamma \sigma_{P}^{2}} .
$$

Second, if the pension fund only uses its available funding to purchase bonds, it invests $m P=A$ in bonds and the value function is:

$$
F \mu_{P}+\frac{\gamma}{2} F^{2} \sigma_{P}^{2}
$$

Third, if the fund allocates its maximum available funding to consols, that is, it invests $m P=A$ in consols, and chooses the optimal allocation $n^{*}$ to swaps. Then, $n^{*}$ is given as:

$$
n=F+\frac{\mu_{P}-(r-\delta)}{\gamma \sigma_{P}^{2}}
$$

and the value of its minimization problem is:

$$
F(r-\delta)-\frac{1}{2} \frac{\left(\mu_{P}-(r-\delta)\right)^{2}}{\gamma \sigma_{P}^{2}}
$$

Comparing Equations (A4) and (A6) we can see that $-\delta<\phi$ is a sufficient condition for the pension fund to prefer swaps over consols. Comparing Equations (A5) and (A6), we find that the fund prefers using swaps over not hedging if:

$$
F\left(\mu_{P}-r\right)+\frac{\gamma}{2} F^{2} \sigma_{P}^{2} \geq-\delta F-\frac{1}{2} \frac{\left(\mu_{P}-(r-\delta)\right)^{2}}{\gamma \sigma_{P}^{2}}
$$

Hence, a sufficient condition for the pension fund to hedge is given as $\delta \geq-\left(\mu_{P}-r\right)-$ $\frac{\gamma}{2} F \sigma_{P}^{2}$ and, under the assumptions in Proposition 1, the corner solution where the pension 
fund uses swaps is preferred over the other two corner solutions.

To ensure that $m^{*}=A / P$ and $n^{*}=F+\frac{\mu_{P}-(r-\delta)}{\gamma \sigma_{P}^{2}}$ are indeed the optimal investments for the pension fund, we plug $m^{*}=(A-x) / P$ and $n^{*}=F+\frac{\mu_{P}-(r-\delta}{\gamma \sigma_{P}^{2}}+y$ into Equation (A1). For $x \leq 0$, the solution to the minimization problem is:

$$
F(r-\delta)-\frac{1}{2} \frac{\left(\mu_{P}-(r-\delta)\right)^{2}}{\gamma \sigma_{P}^{2}}-x(\phi+\delta)+\frac{\gamma}{2} \sigma_{P}^{2}(x-y)^{2}
$$

By assumption, $\phi+\delta>0$ and because $\delta \leq 0$ we assumed $x \leq 0$, the term $-x(\phi+\delta)$ is minimized for $x=0$. With $x=0$, the last term simplifies to $\frac{\gamma}{2} \sigma_{P}^{2} y^{2}$, which is minimized for $y=0$. Analoguously, for $x \geq 0$, the we need to set $\phi=0$ in equation A7 and, again, the expression is minimized for $x=y=0$.

\section{Proof of Proposition 2}

The supply of swaps can be derived from Equation(A2):

$$
s=-\frac{\delta}{a \sigma^{2}}
$$

We first assume that the pension fund's demand for swaps is given by Equation (2), which leads to the equilibrium swap spread in Equation (3).

With that, we can show that, for $a<\gamma$, the equilibrium swap spread satisfies the hedging condition stated in Proposition 1, which completes the proof.

\section{Appendix B. Data Description}

This appendix provides additional details about the data used for our analysis. 
1. Swap Spreads: Swap rates and government bond yields for 2, 3, 5, 10, and 30 years to maturity are obtained from the Bloomberg system. The swap rates are the fixed rates an investor would receive on a semi-annual basis at the current date in exchange for quarterly Libor payments. The U.S. treasury yields are the yields of the most recently auctioned issue and adjusted to reflect constant time to maturity. For 3-year and 7-year treasury yields, we supplement the Bloomberg data with treasury yields from the FED H.15 reports due to several missing observations in the Bloomberg data. Swap spreads are computed as the difference between swap rate and treasury yield, where the swap rate is adjusted to reflect the different daycount conventions which are actual/360 for swaps and actual/actual for treasuries.

2. Underfunded Ratio $(U F R)$ : For the U.S., quarterly data on two types of defined benefit (DB) pension plans, private as well as public local government pension plans, are obtained from the financial accounts of the U.S. (former flow of funds) tables L.118b and L.120b. UFR in quarter $t$ is then computed using Equation (4). Next, positive and negative part are defined as $U F R_{t}^{+}:=\max \left(U F R_{t}, 0\right)$ and $U F R_{t}^{-}:=$ $\min \left(U F R_{t}, 0\right)$. Changes in $U F R$ in the different regimes are computed as $\Delta U F R_{t}^{+}:=$ $\left(U F R_{t}-U F R_{t-1}\right) \mathbb{1}_{\left\{U F R_{t}>0\right\}}$ and $\left(\Delta U F R_{t}^{-}:=\left(U F R_{t}-U F R_{t-1}\right) \mathbb{1}_{\left\{U F R_{t} \leq 0\right\}}\right.$. For Japan, we obtain DB pension funds' claims on sponsor as well as total financial assets from Japan's flow of funds tables. For the Netherlands, we collect data on "liquid assets at the funds' risk" and "estimated technical provision at funds' risk' from the Dutch central banks' website and construct the $U F R$ proxy according to Equation 7 .

3. Libor-repo spread: For the U.S., the 3-month Libor rate as well as the 3-month general collateral repo rate are obtained from the Bloomberg system. Similarly, for Japan, the 6-months general collateral repo rate and the 6-months JPY Libor rate are 
obtained from Bloomberg. The Libor-repo spread is then computed as the difference between these two variables.

4. Debt-to-GDP ratio: Quarterly data on the U.S. debt-to-GDP are obtained from the federal reserve bank of St. Louis which provides a seasonally-adjusted time series.

5. Broker-Dealer EDF: Expected default frequencies are provided by Moody's analytics and we use the equally-weighted average of the 14 largest derivatives-dealing banks (G14 banks). These 14 banks are: Morgan Stanley, JP Morgan, Bank of America, Wells Fargo, Citigroup, Goldman Sachs, Deutsche Bank, Societe Generale, Barclays, HSBC, BNP Paribas, Credit Suisse, Royal Bank of Scottland, and UBS.

6. Move Index: The Move index is computed as the 1-month implied volatility of U.S. treasury bonds with 2,5,10, and 30 years to maturity. Index levels are obtained from the Bloomberg system.

7. Term Factor: This factor captures the slope of the yield curve, measured as the difference between the 30-year treasury yield and the 3-month treasury yield. A description of these yields can be found under point 1 (swap spreads).

8. Level: The level of the yield curve is captured by the 30-year treasury yield. For a description of this yield see point 1 (swap spreads).

9. VIX: Is the implied volatility of the S\&P 500 index and data on VIX are obtained from the Bloomberg System.

10. On-the-run spread: The spread is computed for bonds with 10-years to maturity because estimates of the 30-year spread are noisy and suffer from the 2002-2005 period where the U.S. treasury reduced its debt issuance. The 10-year on-the-run yield is obtained from the FED H.15 website and the 10-year off-the-run yield is constructed as explained in Gürkaynak, Sack, and Wright (2007) and data are obtained from http: 
//www.federalreserve.gov/pubs/feds/2006.

11. Broker-Dealer Leverage: This variable captures the leverage of U.S. broker-dealers and is described in more detail in Adrian et al. (2014). Until Q4 2009, data on this variable are obtained from Tyler Muir's website. Since the data ends in Q4 2009, we use the financial accounts of the U.S. data, following the procedure described in Adrian et al. (2014) to supplement the time series with more recent observations for the Q1 2010 - Q4 2015 period.

12. Mortage Refinancing: Quarterly mortgage origination estimates are directly obtained from the Mortgage Bankers Association website. We use mortgage originations due to refinancing as a proxy for the mortgage refinancing rate.

13. U.S. stock market returns: The U.S. stock returns are quarterly returns of the CRSP value-weighted portfolio in excess of the risk-free rate and obtained from Kenneth French's website.

14. CDS premiums on the U.S. treasury: The U.S. CDS premiums are 5-year CDS premiums of Euro-denominated CDS contracts (which are the most liquidly traded CDS contracts on the U.S. treasury). The data are obtained from Markit.

15. MBS Outstanding: These are the total amount of U.S. agency MBS outstanding. The data are obtained from SIFMA website.

16. Corporate bond issuance: The quarterly issuance of all U.S. investment grade and non-investment grade bonds were provided to us courtesy to SIFMA.

17. EPU data: We use two categories of the economic policy uncertainty (EPU) index, proposed by Baker et al. (2016). These two categories are "government spending" and "debt ceiling" and available under www.policyuncertainty.com

18. U.S. recession probabilities These are the smoothed recession probabilities, es- 
timated in Chauvet and Piger (2008). The data are obtained from Jeremy Piger's website.

\section{Notes}

${ }^{1}$ The leverage implications of IRS on pension sponsors are not investigated in this paper.

${ }^{2}$ See, for instance, https://self-evident.org/?p=780.

${ }^{3}$ See, for instance, Van Deventer 2012).

${ }^{4}$ Another factor that should contribute to the positive level of swap spreads is that the income from holding treasuries is not taxable for state income tax, while income related to the Libor rate typically is (see Elton, Gruber, Agrawal, and Mann, 2001). This "tax spread" could be an additional reason for the high level of swap spreads before the financial crisis and makes the negative swap spread even more surprising.

${ }^{5}$ The prolonged drop in interest rates, following the crisis of 2008, increased the duration of pension liabilities and the monetary policy of the Fed also might have contributed to the overall drop in other interest rates and spreads.

${ }^{6}$ In this analysis, we also include swap spreads with 7 years and 20 years to maturity. Data for these maturities are obtained from the FED H.15 website.

${ }^{7}$ This number is a first approximation that we obtained from http://www . cmegroup.com/ clearing/financial-and-collateral-management/. They analyze haircuts for securities posted as collateral in cleared derivatives transactions. However, market participants confirm that $6 \%$ is a reasonable proxy for haircuts of Treasuries with 30 years to maturity.

${ }^{8}$ There may be other frictions such as taxes that may also favor IRS relative to repo. In the U.S., Internal Revenue Service views repo as financing that would subject the pension plan 
to tax filings as Unrelated Business Income (UBI). Most U.S. pension plans will therefore avoid UBI taxes by avoiding repo and relying on IRS, which does not invoke UBI taxes. We thank Scott McDermott for alerting us to this point.

${ }^{9}$ See http://www . bloomberg.com/apps/news?pid=newsarchive\&sid=aUq.d1dYuhEA

${ }^{10}$ These surveys are available under http://www.ai-cio.com/surveys/.

${ }^{11}$ Feldhütter and Lando (2008) argue that using IRS is the predominant way for doing this as opposed to using Treasuries.

${ }^{12}$ Insurance companies could be another big demander for receiving the fixed rate in longterm swaps, but we have no data available to characterize their funding status. In addition to insurance companies, recent long-term corporate bond issuance might also create a demand for receiving fixed in long-dated interest rate swaps. This is because companies may hedge the duration risk of their bond issuance.

${ }^{13}$ We provide further details about this hedging strategy in Table IA.4 in the internet appendix.

${ }^{14}$ Another friction we abstract away from in this discussion is the possible presence of credit risk in U.S. Treasuries. The reason for doing so is that it is not obvious how an increase in credit risk in U.S. Treasuries might affect the swap spread. Clearly, an increase in treasury credit risk would increase the treasury yield and assuming all else equal, a decrease in the swap spread would result. However, it is not obvious that swap rates would be unaffected by the increase in treasury credit risk since interbank lending rates would presumably increase sharply when U.S. credit risk increases. Therefore, it is just as likely that the swap rate would be elevated.

${ }^{15}$ The Financial Accounts report assets and liabilities (and corresponding financial flows) for both private and public DB pension funds. Prior to September 2013, the assets and 
liabilities of DB pension plans were reported using cash accounting principles, which record the revenues of pension funds when cash is received and expenses when cash is paid out. Under this treatment, there was no measure of a plan's accrued actuarial liabilities. Rather, the liabilities in the Financial Accounts were set equal to the plans' assets. As a result, the Financial Accounts did not report any measure of underfunding or overfunding of the pension sector's actuarial liabilities, as would occur if the assets held by the pension sector fell short of or exceeded the liabilities. Starting with the September 2013 release, the Financial Accounts treat DB pensions using accrual accounting principles, whereby the liabilities of DB pension plans are set equal to the present value of future DB benefits that participants have accumulated to date, which are calculated using standard actuarial methods. This new measure is retroactively made available. Throughout, we use the accrual measures of the claims of pension funds on sponsors.

${ }^{16}$ See Stefanescu and Vidangos (2014) for further details.

${ }^{17}$ We use changes in these variables since both are highly serially correlated. A regression of the level of the 30-year swap spread (level of $U F R$ ) on the lagged level of the 30-year swap spread $(U F R)$ gives a highly significant coefficient of 0.95 (0.97).

${ }^{18}$ Two other control variables that we do not add to this regression are the U.S. agency MBS issuance and the total amount of all IRS outstanding. Unfortunately, these data are only available at an annual and semi-annual frequency, respectively. In unreported robustness checks, we used annual and semi-annual data and found that controlling for these variables does not affect the link between $U F R$ and swap spreads.

${ }^{19}$ We focus on $2,5,10$, and 30-year swap spreads since there are no missing observations for these data and we do not need to supplement them with data from the FED H.15 reports.

${ }^{20}$ According to SIFMA, the average maturity of newly issued bonds varied from 7.3 years 
in the year 2000 to 17.0 in the year 2015. Hence, the issuance of long-dated corporate bonds might generate a hedging demand for long-dated IRS by corporations.

${ }^{21}$ We thank the referees for suggesting this extension to international markets.

${ }^{22}$ Due to data constraints and the use of inflation-linked pension plans, we did not pursue the pension schemes in Australia and the U.K.

${ }^{23}$ As stated by Deutsche Bank markets research: "One of the major risks that Dutch pension funds run is interest rate risk and hence their reduced ability to take risk could on the margin increase receiving pressure [...] from the Durch pension fund community" (Singhania, 2015).

${ }^{24}$ We only include data up until Q4 2014 because from Q1 2015, the policy funding ratio is not based on the current ratio between assets and liabilities anymore but on the average funding ratio over the past year.

${ }^{25}$ Note that this problem is equivalent to the pension fund maximizing its level of funding, $A-L P<0$, that is:

$$
\max _{m, n}\left[\mathbb{E}[A-L P]-\frac{\gamma}{2} \operatorname{Var}(A-L P)\right] .
$$




\section{REFERENCES}

Abad, Jorge, Iñaki Aldasoro, Christoph Aymanns, Marco D’Errico, Linda Fache Rousová, et al., 2016, Shedding light on dark markets: First insights from the new eu-wide otc derivatives dataset, European Systemic Risk Board.

Adams, James, and Donald J Smith, 2009, Mind the gap: using derivatives overlays to hedge pension duration, Financial Analysts Journal 65, 60-67.

Adrian, Tobias, Erkko Etula, and Tyler Muir, 2014, Financial intermediaries and the crosssection of asset returns, Journal of Finance 69, 2557-2596.

Ang, Andrew, Bingxu Chen, and Suresh Sundaresan, 2013, Liability-driven investment with downside risk, Journal of Portfolio Management 40, 71.

Baker, Scott R, Nicholas Bloom, and Steven J Davis, 2016, Measuring economic policy uncertainty, Quarterly Journal of Economics 131, 1593-1636.

CGFS, 2011, Fixed income strategies of insurance companies and pension funds, Bank for International Settlements, Committee on the Global Financial System.

Chauvet, Marcelle, and Jeremy Piger, 2008, A comparison of the real-time performance of business cycle dating methods, Journal of Business $\&$ Economic Statistics 26, 42-49.

Chernenko, Sergey, and Michael Faulkender, 2012, The two sides of derivatives usage: Hedging and speculating with interest rate swaps, Journal of Financial and Quantitative Analysis 46, 1727-1754.

Collin-Dufresne, Pierre, and Bruno Solnik, 2001, On the term structure of default premia in the swap and libor markets, Journal of Finance 56, 1095-1115. 
Domanski, Dietrich, Hyun Song Shin, and Vladyslav Sushko, 2015, The hunt for duration: not waving but drowning?, BIS Working Paper.

Duarte, Jefferson, Francis A Longstaff, and Fan Yu, 2007, Risk and return in fixed-income arbitrage: Nickels in front of a steamroller?, Review of Financial Studies 20, 769-811.

Duffie, Darrell, and Kenneth J Singleton, 1997, An econometric model of the term structure of interest-rate swap yields, Journal of Finance 52, 1287-1321.

Elton, Edwin J, Martin J Gruber, Deepak Agrawal, and Christopher Mann, 2001, Explaining the rate spread on corporate bonds, Journal of Finance 56, 247-277.

Faulkender, Michael, 2005, Hedging or market timing? selecting the interest rate exposure of corporate debt, Journal of Finance 60, 931-962.

Feldhütter, Peter, and David Lando, 2008, Decomposing swap spreads, Journal of Financial Economics 88, 375-405.

Gârleanu, Nicolae, and Lasse Heje Pedersen, 2011, Margin-based Asset Pricing and Deviations from the Law of One Price, Review of Financial Studies 24, 1980-2022.

Garleanu, Nicolae, Lasse Heje Pedersen, and Allen M Poteshman, 2009, Demand-based option pricing, Review of Financial Studies 22, 4259-4299.

Greenwood, Robin, and Dimitri Vayanos, 2010, Price pressure in the government bond market, American Economic Review 585-590.

Grinblatt, Mark, 2001, An analytic solution for interest rate swap spreads, International Review of Finance 2, 113-149. 
Gromb, Denis, and Dimitri Vayanos, 2002, Equilibrium and welfare in markets with financially constrained arbitrageurs, Journal of Financial Economics 66, 361-407.

Gromb, Denis, and Dimitri Vayanos, 2010, Limits of Arbitrage, Annual Review of Financial Economics 2, 251-275.

Gürkaynak, Refet S, Brian Sack, and Jonathan H Wright, 2007, The us treasury yield curve: 1961 to the present, Journal of Monetary Economics 54, 2291-2304.

Hanson, Samuel G, 2014, Mortgage convexity, Journal of Financial Economics 113, 270-299.

Jermann, Urban J, 2016, Negative swap spreads and limited arbitrage, Working paper, Wharton School.

Jermann, Urban J, and Vivian Z Yue, 2013, Interest rate swaps and corporate default, ECB Working Paper.

Johannes, Michael, and Suresh Sundaresan, 2007, The impact of collateralization on swap rates, Journal of Finance 62, 383-410.

Klingler, Sven, and David Lando, 2016, Safe haven cds pemiums, Working Paper, Copenhagen Business School.

Krishnamurthy, Arvind, 2010, How debt markets have malfunctioned in the crisis, Journal of Economic Perspectives 24, 3-28.

Krishnamurthy, Arvind, and Annette Vissing-Jorgensen, 2012, The aggregate demand for treasury debt, Journal of Political Economy 120, 233-267.

Lang, Larry HP, Robert H Litzenberger, and Andy Luchuan Liu, 1998, Determinants of interest rate swap spreads, Journal of Banking $\& 3$ Finance 22, 1507-1532. 
Leising, Matthew, 2013, U.s. approves $\$ 6.8$ trillion in pension funds for cleared swaps, Bloomberg article.

Liu, Jun, and Francis A Longstaff, 2004, Losing money on arbitrage: Optimal dynamic portfolio choice in markets with arbitrage opportunities, Review of Financial Studies 17, $611-641$.

Liu, Jun, Francis A Longstaff, and Ravit E Mandell, 2006, The market price of risk in interest rate swaps: the roles of default and liquidity risks, Journal of Business 79, 2337-2359.

Longstaff, Francis A, 2004, The flight-to-liquidity premium in us treasury bond prices, Journal of Business 77, 511-526.

Lou, Wujiang, 2009, On asymmetric funding of swaps and derivatives-a funding cost explanation of negative swap spreads, Working paper available at SSRN.

Musto, David, Greg Nini, and Krista Schwarz, 2014, Notes on bonds: Liquidity at all costs in the great recession, Working paper, University of Pennsylvania.

OECD, 2016, Pension funds in figures, Research note, OECD.

Ring, Ed, 2014, Estimating americas total unfunded state and local government pension liability, California Policy Centerr.

Shleifer, Andrei, and Robert W Vishny, 1997, The limits of arbitrage, Journal of Finance $52,35-55$.

Singhania, Abhishek, 2015, Dutch ufr curve adjustment, Deutsche Bank Markets Research. 
Stefanescu, Irina, and Ivan Vidangos, 2014, Introducing actuarial liabilities and funding status of defined-benefit pensions in the u.s. financial accounts, Technical report, FEDS Notes.

Sundaresan, Suresh, and Fernando Zapatero, 1997, Valuation, optimal asset allocation and retirement incentives of pension plans, Review of Financial Studies 10, 631-660.

Van Deventer, Donald R., 2012, Why is the 30 year swap spread to treasuries negative?, Kamakura report.

Vasicek, Oldrich, 1977, An equilibrium characterization of the term structure, Journal of Financial Economics 5, 177-188. 


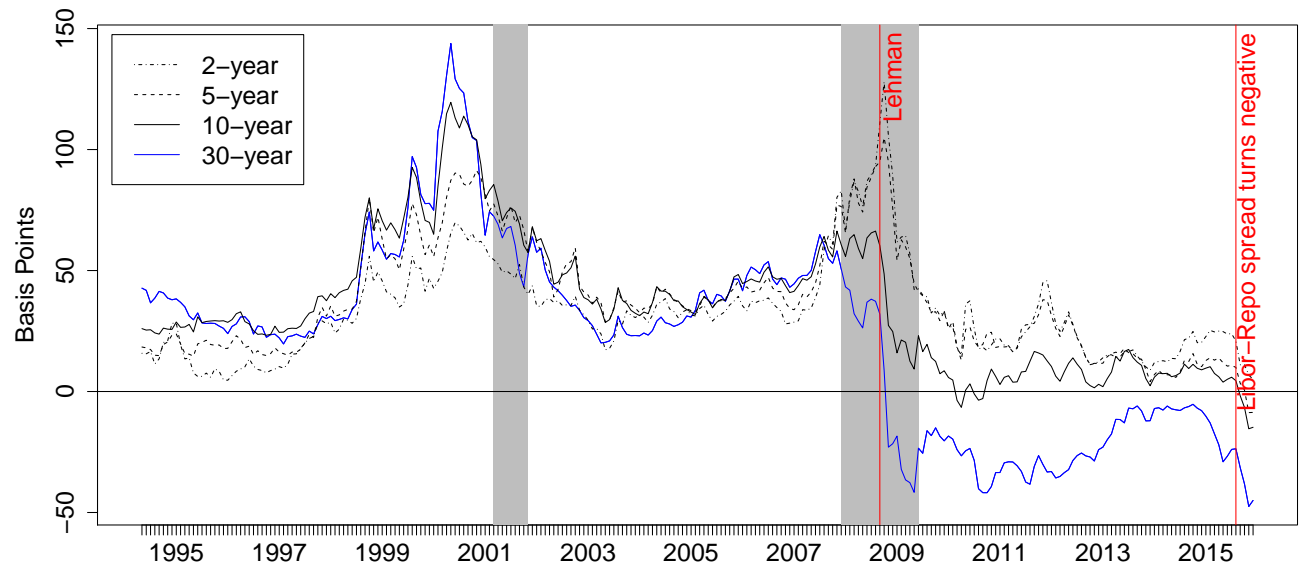

Figure 1. Term structure of interest rate swap spreads: The graph shows the history of swap spreads (monthly averages) from May 1994 until December 2015. The grey shaded areas represent U.S. recession periods. The source for our data is Bloomberg. The differences in market conventions have been taken into account in computing the spreads 

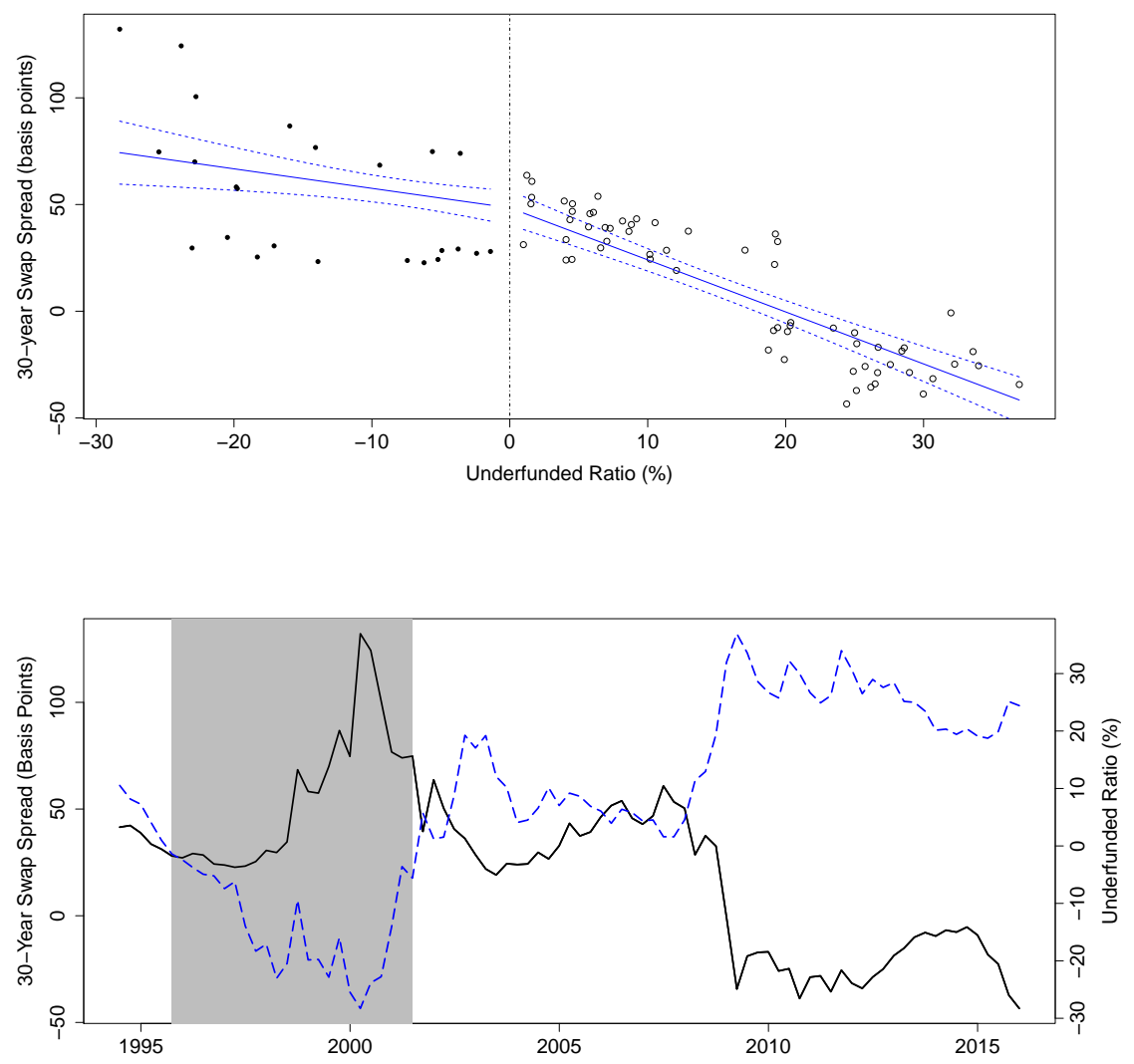

Figure 2. Relationship between 30-year swap spreads and the aggregate funding status of DB pension plans. The lower panel shows the time series of the two variables, wherein the black solid line is the 30-year swap spread (left-hand axis) and the blue dotted line is pension funds' underfunded ratio (right-hand side). The grey shaded areas indicate periods where pension funds are fully funded or over-funded. Data on pension fund underfunding ratios are obtained from the financial accounts of the U.S. and the underfunding ratio is computed as indicated in Equation (4). 
Table I

\section{OLS Regressions of Swap Spreads on Principal Components}

For each of the two sub-periods, $P C 1$ and $P C 2$ are the first and second principal components of the term structure of swap spreads for this sub period. We use monthly treasury yields and swap rates from the Bloomberg system to compute swap spreads. 3-year and 7-year treasury data are supplemented using data from the FED H15 reports. The sample period is May 1994 - December 2015. $\hat{\beta}$ is the estimated loading on the respective PC.

\begin{tabular}{|c|c|c|c|c|c|c|c|c|}
\hline & \multicolumn{4}{|c|}{ Pre September 2008} & \multicolumn{4}{|c|}{ Post September 2008} \\
\hline & \multicolumn{2}{|c|}{$\mathrm{PC} 1$} & \multicolumn{2}{|c|}{$\mathrm{PC} 2$} & \multicolumn{2}{|c|}{$\mathrm{PC} 1$} & \multicolumn{2}{|c|}{$\mathrm{PC} 2$} \\
\hline & $\hat{\beta}$ & $R^{2}$ & $\hat{\beta}$ & $R^{2}$ & $\hat{\beta}$ & $R^{2}$ & $\hat{\beta}$ & $R^{2}$ \\
\hline $2 \mathrm{yr}$ & 0.33 & $78.0 \%$ & 0.41 & $18.2 \%$ & 0.53 & $97.0 \%$ & -0.03 & $0.1 \%$ \\
\hline $3 \mathrm{yr}$ & 0.33 & $74.4 \%$ & 0.46 & $23.1 \%$ & 0.56 & $98.1 \%$ & -0.01 & $0.0 \%$ \\
\hline $5 \mathrm{yr}$ & 0.40 & $91.1 \%$ & 0.26 & $6.0 \%$ & 0.45 & $97.9 \%$ & 0.04 & $0.2 \%$ \\
\hline $7 \mathrm{yr}$ & 0.37 & 94.1 & 0.16 & $2.8 \%$ & 0.36 & $86.5 \%$ & -0.14 & $2.8 \%$ \\
\hline $10 \mathrm{yr}$ & 0.43 & $94.8 \%$ & -0.14 & $1.7 \%$ & 0.19 & $64.4 \%$ & -0.26 & $24.8 \%$ \\
\hline $20 \mathrm{yr}$ & 0.35 & $78.1 \%$ & -0.42 & $17.3 \%$ & -0.20 & $24.8 \%$ & -0.71 & $70.2 \%$ \\
\hline $30 \mathrm{yr}$ & 0.42 & $77.0 \%$ & -0.57 & $21.5 \%$ & 0.06 & $3.1 \%$ & -0.64 & $85.6 \%$ \\
\hline
\end{tabular}




\section{Table II}

\section{Illustration of the Cashflows from Different Strategies}

This table shows the cashflows of two possible strategies to meet the pension obligations $L$, assuming that the pension fund has already purchased $\frac{A}{P}$ bonds. The first strategy, illustrated in Panel A, consists of a receiver position in an IRS with notional amount $n=L P-A$, where we assume that the fixed rate on the swap is $c=1 / P$. The second strategy, illustrated in Panel $\mathrm{B}$, consists of borrowing $L P-A$ dollors to establish an additional position of $L-\frac{A}{P}$ bonds.

\begin{tabular}{lllll}
\hline $\begin{array}{c}\text { Transaction } \\
\text { at } \mathrm{t}=0\end{array}$ & \multicolumn{1}{c}{$\begin{array}{c}\text { Cashflow } \\
\mathrm{t}=1\end{array}$} & $\begin{array}{c}\text { Cashflow } \\
\mathrm{t}=2\end{array}$ & $\ldots$ & \multicolumn{1}{c}{$\begin{array}{c}\text { Cashflow } \\
\mathrm{t}=\mathrm{s}\end{array}$} \\
\hline & \multicolumn{4}{c}{ Panel A: Using swaps in perfect markets } \\
\hline Receive fixed in IRS & $L-A / P$ & $L-A / P$ & $\ldots$ & $L-A / P$ \\
Pay floating in IRS & $(L P-A) r_{1}$ & $(L P-A) r_{2}$ & $\ldots$ & $(L P-A) r_{s}$ \\
\hline \multicolumn{5}{l}{ Panel B: Using bonds and repo transactions } \\
\hline Receive bond cashflows & $L-A / P$ & $L-A / P$ & $\ldots$ & $L-A / P$ \\
Pay funding cost & $(L P-A)\left(r_{1}+\phi\right)$ & $(L P-A)\left(r_{2}+\phi\right)$ & $\ldots$ & $(L P-A)\left(r_{s}+\phi\right)$ \\
\hline
\end{tabular}




\section{Table III}

\section{Aggregate Pension Fund Balance Sheet as of Q3 2015}

This table presents the assets and liabilities of private as well as state and local government employee defined-benefit (DB) pension plans. The amounts are in billions of dollars, not seasonally adjusted. (Source: Financial accounts of the United States)

\begin{tabular}{lrrr}
\hline \multicolumn{2}{c}{ DB Pension Fund Assets (billions) } & \multicolumn{1}{c}{ DB Pension Fund Liabilities } \\
\hline checkable deposits and currency & $\$ 14.42$ & pension entitlements & $\$ 8,430.73$ \\
total time and savings deposits & $\$ 75.67$ & & \\
money market mutual fund shares & $\$ 85.45$ & & \\
security repurchase agreements & $\$ 7.11$ & & \\
debt securities & $\$ 1,744.41$ & & \\
commercial paper & $\$ 82.26$ & & \\
Treasury securities & $\$ 365.19$ & & \\
agency- and GSE-backed securities & $\$ 191.15$ & & \\
corporate and foreign bonds & $\$ 1,101.75$ & & \\
municipal securities & $\$ 4.05$ & & \\
total mortgages & $\$ 20.00$ & & \\
corporate equities & $\$ 3,141.21$ & & \\
mutual fund shares & $\$ 613.29$ & & \\
miscellaneous assets & $\$ 2,533.58$ & & \\
unallocated insurance contracts & $\$ 58.02$ & & \\
pension fund contributions receivable & $\$ 47.28$ & & \\
claims of pension fund on sponsor & $\$ 2,044.53$ & & \\
unidentified miscellaneous assets & $\$ 383.76$ & & \\
\hline TOTAL & $\$ 8,235.12$ & TOTAL & \\
\hline
\end{tabular}




\section{Table IV \\ 30-Year Swap Spreads and Pension Fund Underfunding}

This table reports results from regressions of quarterly changes in the 30-year swap spread on the indicated variables. $\triangle U F R_{t}$ is the change in the underfunding ratio of private and local government defined benefit pension funds, as defined in Equation (4), $\triangle U F R_{t}^{+}\left(\Delta U F R_{t}^{-}\right)$is the change in $U F R_{t}$ if $U F R_{t}>0$ $\left(U F R_{t} \leq 0\right)$ and zero otherwise. $\Delta L R$ Spread $_{t}$ is the change in the difference between the 3-month Libor rate and 3-month General Collateral repo rate, $\Delta D e b t / G D P_{t}$ is the change in the ratio of U.S. public debt to GDP, $\triangle E D F_{t}$ is the change in the Moody's expected default frequency of the 14 largest derivatives-dealing banks (G14 banks), $\Delta$ Move $_{t}$ is the change in the 1-month implied volatility of U.S. Treasuries with 2,5, 10 , and 30 years to maturity, $\triangle T E R M_{t}$ measures changes in the slope of the yield curve, approximated as the difference between 30-year and 3-month treasury yields, and $\log \left(E P U_{t}^{\text {DebtCeil }}\right)$ is a version of the policy uncertainty index by Baker et al. (2016) that captures uncertainty about the debt ceiling. The additional controls include changes in the following variables: the level of the 30-year treasury yield, the U.S. mortgage refinancing rate, agency MBS outstanding, the VIX index, the 10-year on-the-run-off-the-run spread, U.S. recession probabilities, as well as the levels of the Adrian et al. (2014) broker-dealer leverage factor and uncertainty about government spending. All variables are quarter-end. The numbers in parenthesis are heteroskedasticity-robust $t$-statistics. ${ }^{* * *},{ }^{* *}$, and ${ }^{*}$ indicate significance at a $1 \%, 5 \%$, and $10 \%$ level respectively. The observation period is Q3 1994 - Q4 2015 with 5 missing observations between Q4 1997 and Q4 1998 due to missing repo rates.

\begin{tabular}{|c|c|c|c|c|c|c|}
\hline & (1) & (2) & (3) & (4) & (5) & (6) \\
\hline Intercept & $\begin{array}{l}-1.14 \\
(-0.91)\end{array}$ & $\begin{array}{l}-1.05 \\
(-0.85)\end{array}$ & $\begin{array}{l}-0.59 \\
(-0.41)\end{array}$ & $\begin{array}{l}-0.53 \\
(-0.37)\end{array}$ & $\begin{array}{l}25.60^{*} \\
(1.78)\end{array}$ & $\begin{array}{l}26.03^{*} \\
(1.78)\end{array}$ \\
\hline$\Delta U F R_{t}$ & $\begin{array}{l}-1.08^{* * *} \\
(-2.94)\end{array}$ & & $\begin{array}{l}-0.96^{* *} \\
(-2.19)\end{array}$ & & $\begin{array}{l}-0.68 \\
(-1.37)\end{array}$ & \\
\hline$\Delta U F R_{t}^{+}$ & & $\begin{array}{l}-1.32^{* * *} \\
(-3.46)\end{array}$ & & $\begin{array}{l}-1.27^{* * *} \\
(-3.18)\end{array}$ & & $\begin{array}{l}-1.19^{* *} \\
(-2.40)\end{array}$ \\
\hline$\Delta U F R_{t}^{-}$ & & $\begin{array}{l}-0.55 \\
(-0.78)\end{array}$ & & $\begin{array}{l}-0.47 \\
(-0.59)\end{array}$ & & $\begin{array}{l}-0.27 \\
(-0.34)\end{array}$ \\
\hline$\Delta L R$ Spread $_{t}$ & $\begin{array}{c}0.05 \\
(1.06)\end{array}$ & $\begin{array}{c}0.05 \\
(1.21)\end{array}$ & $\begin{array}{c}0.01 \\
(0.15)\end{array}$ & $\begin{array}{c}0.01 \\
(0.22)\end{array}$ & $\begin{array}{l}-0.04 \\
(-0.52)\end{array}$ & $\begin{array}{l}-0.04 \\
(-0.53)\end{array}$ \\
\hline$\Delta D e b t / G D P_{t}$ & & & $\begin{array}{l}-1.04 \\
(-1.34)\end{array}$ & $\begin{array}{l}-0.96 \\
(-1.24)\end{array}$ & $\begin{array}{l}-0.53 \\
(-0.69)\end{array}$ & $\begin{array}{l}-0.40 \\
(-0.57)\end{array}$ \\
\hline$\Delta E D F_{t}$ & & & $\begin{array}{l}-0.05^{* *} \\
(-2.12)\end{array}$ & $\begin{array}{l}-0.03 \\
(-1.65)\end{array}$ & $\begin{array}{l}-0.07^{*} \\
(-1.88)\end{array}$ & $\begin{array}{l}-0.06 \\
(-1.48)\end{array}$ \\
\hline$\Delta$ Move $_{t}$ & & & $\begin{array}{l}0.17^{* *} \\
(2.56)\end{array}$ & $\begin{array}{l}0.17^{* *} \\
(2.58)\end{array}$ & $\begin{array}{l}0.24^{* *} \\
(2.54)\end{array}$ & $\begin{array}{l}0.23^{* *} \\
(2.37)\end{array}$ \\
\hline$\Delta T E R M_{t}$ & & & $\begin{array}{l}-0.05^{*} \\
(-1.76)\end{array}$ & $\begin{array}{l}-0.06^{* *} \\
(-2.00)\end{array}$ & $\begin{array}{l}-0.06 \\
(-1.38)\end{array}$ & $\begin{array}{l}-0.06 \\
(-1.43)\end{array}$ \\
\hline $\log \left(E P U_{t}^{\text {DebtCeil }}\right)$ & & & 55 & & $\begin{array}{l}1.39^{* *} \\
(2.09)\end{array}$ & $\begin{array}{l}1.42^{* *} \\
(2.10)\end{array}$ \\
\hline Add. Controls? & No & No & No & No & Yes & Yes \\
\hline $\begin{array}{l}\text { Observations } \\
\text { Adjusted } \mathrm{R}^{2}\end{array}$ & $\begin{array}{c}81 \\
0.15\end{array}$ & $\begin{array}{c}81 \\
0.15\end{array}$ & $\begin{array}{c}81 \\
0.27\end{array}$ & $\begin{array}{c}81 \\
0.28\end{array}$ & $\begin{array}{c}81 \\
0.28\end{array}$ & $\begin{array}{c}81 \\
0.29\end{array}$ \\
\hline
\end{tabular}




\section{Table V}

\section{Pension Fund Underfunding and Swap Spreads With Different Maturities}

This table reports results from regressions of quarterly changes in swap spreads with $2,5,10$, and 30 years to maturity on the indicated variables. $\Delta U F R_{t}^{+}\left(\Delta U F R_{t}^{-}\right)$is the change in the underfunding ratio of private and local government defined benefit pension funds as defined in Equation (4), conditional on pension funds being underfunded (funded) at time t. $\Delta L R \operatorname{Spread}_{t}$ is the change in the quarter-end difference between the 3-month Libor rate and 3-month General Collateral repo rate. The numbers in parenthesis are heteroskedasticity-robust $t$-statistics. ${ }^{* * *},{ }^{* *}$, and * indicate significance at a 1\%, 5\%, and 10\% level respectively. The observation period is Q3 1994 - Q4 2015 with 5 missing observations between Q4 1997 and Q4 1998 due to missing repo rates.

\begin{tabular}{lcccc}
\hline & 2 Year & 5 Year & 10 Year & 30 Year \\
\hline Intercept & -0.02 & -0.48 & -0.73 & -1.05 \\
& $(-0.02)$ & $(-0.48)$ & $(-0.66)$ & $(-0.85)$ \\
$\Delta U F R_{t}^{+}$ & -0.05 & 0.04 & -0.32 & $-1.32^{* * *}$ \\
& $(-0.12)$ & $(0.09)$ & $(-0.81)$ & $(-3.46)$ \\
$\Delta U F R_{t}^{-}$ & 0.21 & 0.12 & -0.12 & -0.55 \\
& $(0.44)$ & $(0.30)$ & $(-0.19)$ & $(-0.78)$ \\
$\Delta L R$ Spread $_{t}$ & $0.33^{* * *}$ & $0.18^{* * *}$ & 0.06 & 0.05 \\
& $(4.72)$ & $(3.17)$ & $(1.24)$ & $(1.21)$ \\
\hline Observations $_{\text {Adjusted } \mathrm{R}^{2}}$ & 81 & 81 & 81 & 81 \\
\hline
\end{tabular}




\section{Table VI}

\section{0-Year Swap Spreads and Pension Fund Underfunding (2-Stage Least Squares)}

This table reports results from second stage regressions of quarterly changes in the 30-year swap spread on the indicated variables. In the first stage, the change in the underfunding ratio of private and local government defined benefit pension funds, $\Delta U F R_{t}\left(\Delta U F R_{t}^{+}\right)$is regressed on the excess returns of the CRSP value-weighted portfolio, controlling for the other indicated variables. $\Delta L R$ Spread $_{t}$ is the change in the quarter-end difference between the 3-month Libor rate and 3-month General Collateral repo rate, $\Delta D e b t / G D P_{t}$ is the change in the ratio of U.S. public debt to GDP, $\Delta E D F_{t}$ is the change in the Moody's expected default frequency of the 14 largest derivatives-dealing banks (G14 banks), $\Delta$ Move $_{t}$ is the change in the 1-month implied volatility of U.S. Treasuries with $2,5,10$, and 30 years to maturity , $\triangle T E R M_{t}$ measures changes in the slope of the yield curve, approximated as the difference between 30-year and 3-months treasury yields. A detailed description of the additional controls can be found in the caption of Table IV] All variables are quarter-end. The numbers in parenthesis are small-sample and heteroskedasticity-robust $t$-statistics.***, **, and ${ }^{*}$ indicate significance at a 1\%,5\%, and 10\% level respectively. The observation period is Q3 1994 - Q4 2015 with 5 missing observations between Q4 1997 and Q4 1998 due to missing repo rates.

\begin{tabular}{|c|c|c|c|c|c|c|}
\hline & (1) & $(2)$ & (3) & (4) & $(5)$ & (6) \\
\hline Intercept & $\begin{array}{c}-1.15 \\
(-0.92)\end{array}$ & $\begin{array}{c}-1.62 \\
(-1.45)\end{array}$ & $\begin{array}{c}-0.59 \\
(-0.42)\end{array}$ & $\begin{array}{c}-1.18 \\
(-1.00)\end{array}$ & $\begin{array}{c}24.57^{*} \\
(1.95)\end{array}$ & $\begin{array}{l}11.37 \\
(1.02)\end{array}$ \\
\hline$\Delta U F R_{t}$ & $\begin{array}{l}-1.04^{* * *} \\
(-2.98)\end{array}$ & & $\begin{array}{c}-0.93^{* *} \\
(-2.28)\end{array}$ & & $\begin{array}{c}-0.73^{*} \\
(-1.92)\end{array}$ & \\
\hline$\Delta U F R_{t}^{+}$ & & $\begin{array}{l}-1.27^{* * *} \\
(-3.30)\end{array}$ & & $\begin{array}{l}-1.13^{* * *} \\
(-2.75)\end{array}$ & & $\begin{array}{c}-0.92^{* *} \\
(-2.23)\end{array}$ \\
\hline$\Delta L R$ Spread $_{t}$ & $\begin{array}{c}0.06 \\
(1.06)\end{array}$ & $\begin{array}{c}0.08^{*} \\
(1.85)\end{array}$ & $\begin{array}{c}0.01 \\
(0.17)\end{array}$ & $\begin{array}{c}0.03 \\
(0.78)\end{array}$ & $\begin{array}{c}-0.02 \\
(-0.37)\end{array}$ & $\begin{array}{c}0.03 \\
(0.70)\end{array}$ \\
\hline$\Delta D e b t / G D P_{t}$ & & & $\begin{array}{c}-1.05 \\
(-1.33)\end{array}$ & $\begin{array}{c}-0.73 \\
(-1.12)\end{array}$ & $\begin{array}{c}-1.00 \\
(-1.30)\end{array}$ & $\begin{array}{c}-0.86 \\
(-1.14)\end{array}$ \\
\hline$\Delta E D F_{t}$ & & & $\begin{array}{c}-0.05^{* *} \\
(-2.37)\end{array}$ & $\begin{array}{l}-0.05^{* *} \\
(-2.10)\end{array}$ & $\begin{array}{c}-0.04 \\
(-1.17)\end{array}$ & $\begin{array}{c}-0.04 \\
(-1.03)\end{array}$ \\
\hline$\Delta$ Move $_{t}$ & & & $\begin{array}{l}0.17^{* *} \\
(2.59)\end{array}$ & $\begin{array}{l}0.14^{* *} \\
(2.43)\end{array}$ & $\begin{array}{l}0.20^{* * *} \\
(2.80)\end{array}$ & $\begin{array}{l}0.15^{* *} \\
(2.49)\end{array}$ \\
\hline$\Delta T E R M_{t}$ & & & $\begin{array}{c}-0.05^{*} \\
(-1.75)\end{array}$ & $\begin{array}{l}-0.05^{* *} \\
(-2.11)\end{array}$ & $\begin{array}{c}-0.04 \\
(-1.19)\end{array}$ & $\begin{array}{c}-0.03 \\
(-1.19)\end{array}$ \\
\hline $\log \left(E P U_{t}^{\text {DebtCeil }}\right)$ & & & & & $\begin{array}{l}1.26^{* *} \\
(2.08)\end{array}$ & $\begin{array}{c}0.75 \\
(1.14)\end{array}$ \\
\hline Add. Controls? & No & No & No & No & Yes & Yes \\
\hline Observations & 81 & 62 & 81 & 62 & 81 & 62 \\
\hline
\end{tabular}




\section{Table VII}

\section{Additional Robustness Checks}

This table reports the results of various robustness checks. Panels (1) and (2) show the results of adding $\triangle C D S_{t}$ (the changes in the 5-year CDS premium on the U.S. Treasury) and $\log \left(\right.$ CorporateI ssuance $\left._{t}\right)$ (the issuance of U.S. corporate bonds) as control variables. Panel (3) shows the results of adding a dummy-slope variable $\Delta U F R_{t} \times 1_{\left\{t \geq Q 3^{\prime} 08\right\}}$, that is equal to zero before Q3 2008 and equal to $\Delta U F R_{t}$ from Q3 2008 on. Panel (4) shows the results of adding three dummy slope variables, $\Delta U F R_{t} \times 1_{\left\{t \in\left[Q 3^{\prime} 08, Q 3^{\prime} 09\right)\right\}}, \Delta U F R_{t} \times 1_{\left\{t \in\left[Q 3^{\prime} 09, Q 3^{\prime} 10\right)\right\}}$, and $\Delta U F R_{t} \times 1_{\left\{t \in\left[Q 3^{\prime} 10, Q 3^{\prime} 11\right)\right\}}$, which are equal to $\Delta U F R_{t}$ in quarters that are in the indicator function and zero in all other periods. Panel (5) shows the results of using changes in the modified version of $U F R$, described in Equation (5). The additional controls include changes in the following five variables: the Libor-repo spread, the U.S. debt-to-GDP ratio, the Moody's expected default frequency of the 14 largest derivatives-dealing banks, the Move index, and the difference between 30-year and 3 -month treasury yields. The parameter estimates for these controls are omitted for brevity. All variables are quarter-end. The numbers in parenthesis are heteroskedasticity-robust $t$-statistics. ${ }^{* * *}$, **, and ${ }^{*}$ indicate significance at a 1\%,5\%, and $10 \%$ level respectively. The observation period is Q3 1994 - Q4 2015 with 5 missing observations between Q4 1997 and Q4 1998 due to missing repo rates.

\begin{tabular}{|c|c|c|c|c|c|}
\hline & (1) & $(2)$ & (3) & (4) & (5) \\
\hline Intercept & $\begin{array}{c}-0.20 \\
(-0.15)\end{array}$ & $\begin{array}{l}10.76 \\
(0.15)\end{array}$ & $\begin{array}{c}-0.51 \\
(-0.36)\end{array}$ & $\begin{array}{c}-0.59 \\
(-0.40)\end{array}$ & $\begin{array}{c}-0.59 \\
(-0.42)\end{array}$ \\
\hline$\Delta U F R_{t}^{+}$ & $\begin{array}{c}-0.83^{*} \\
(-1.82)\end{array}$ & $\begin{array}{l}-1.57^{* * *} \\
(-3.05)\end{array}$ & $\begin{array}{l}-1.33^{* * *} \\
(-2.85)\end{array}$ & $\begin{array}{c}-1.17^{* *} \\
(-2.58)\end{array}$ & $\begin{array}{l}-1.13^{* * *} \\
(-3.01)\end{array}$ \\
\hline$\Delta U F R_{t}^{-}$ & & $\begin{array}{c}-2.27 \\
(-1.34)\end{array}$ & $\begin{array}{c}-0.48 \\
(-0.59)\end{array}$ & $\begin{array}{c}-0.48 \\
(-0.59)\end{array}$ & $\begin{array}{c}-0.77 \\
(-0.94)\end{array}$ \\
\hline$\Delta C D S_{t}$ & $\begin{array}{c}-0.23 \\
(-1.47)\end{array}$ & & & & \\
\hline $\log \left(\right.$ CorporateIssuance $\left._{t}\right)$ & & $\begin{array}{c}-0.81 \\
(-0.14)\end{array}$ & & & \\
\hline$\Delta U F R_{t} \times 1_{\left\{t \geq Q 3^{\prime} 08\right\}}$ & & & $\begin{array}{c}0.22 \\
(0.31)\end{array}$ & & \\
\hline$\Delta U F R_{t} \times 1_{\left\{t \in\left[Q 3^{\prime} 08, Q 3^{\prime} 09\right)\right\}}$ & & & & $\begin{array}{l}-1.24^{* *} \\
(-2.03)\end{array}$ & \\
\hline$\Delta U F R_{t} \times 1_{\left\{t \in\left[Q 3^{\prime} 09, Q 3^{\prime} 10\right)\right\}}$ & & & & $\begin{array}{c}0.20 \\
(0.28)\end{array}$ & \\
\hline$\Delta U F R_{t} \times 1_{\left\{t \in\left[Q 3^{\prime} 10, Q 3^{\prime} 11\right)\right\}}$ & & & & $\begin{array}{c}-0.08 \\
(-0.03)\end{array}$ & \\
\hline Add. Controls? & Yes & $Y e s^{58}$ & Yes & Yes & Yes \\
\hline Observations & 48 & 64 & 81 & 81 & 81 \\
\hline Adjusted $\mathrm{R}^{2}$ & 0.47 & 0.37 & 0.27 & 0.27 & 0.27 \\
\hline
\end{tabular}




\section{Table VIII \\ Summary Statistics for International Data}

This table shows summary statistics of pension fund underfunding and 30-year swap spreads for Japan and the Netherlands. $U F R_{t}^{J a p}$ is constructed based on Equation (6). 30-yr SS (Jap) is the difference between the fixed rate in a 30-year IRS where the fixed rate is exchanged against 6-month Japanese Libor rates and the bond yield of the most recently issued Japanese government bond with 30-years to maturity. $U F R_{t}^{\text {Neth }}$ is constructed based on Equation (7). 30-yr SS (Ger) and 30-yr SS (Neth) are the difference between the fixed rate in a 30-year IRS where the fixed rate is exchanged against annual Euribor rates and the bond yield of the most recently issued German or Dutch government bond with 30-years to maturity, respectively. The sample period in Panel A is Q1 2005 - Q4 2015. The sample period in Panel B is Q1 2007 - Q4 2014. \# Under counts the number of quarters where pension funds are underfunded.

\begin{tabular}{lrrrrrrr}
\hline & Mean & SD & Min & Median & Max & \# Obs & \# Under \\
\hline \multicolumn{7}{c}{ Panel A: Summary statistics for Japan } \\
\hline UFR $R_{t}^{\text {Jap }}$ & 28.88 & 7.25 & 17.38 & 28.04 & 41.17 & 44 & 44 \\
30-yr SS (Jap) & -0.11 & 11.73 & -24.94 & -0.65 & 26.34 & 44 & - \\
\hline \multicolumn{7}{c}{ Panel B: Summary statistics for the Netherlands } \\
\hline UF $R_{t}^{\text {Neth }}$ & -8.83 & 11.81 & -34.14 & -7.38 & 8.99 & 32 & 12 \\
30-yr SS (Ger) & 0.16 & 12.31 & -25.85 & 2.04 & 23.10 & 32 & - \\
30-yr SS (Neth) & -11.83 & 15.32 & -47.55 & -14.42 & 16.00 & 32 & - \\
\hline
\end{tabular}




\section{Table IX}

\section{Pension Fund Underfunding and Swap Spreads in Other Regions}

This table reports results from regressions of quarterly changes in swap spreads with 2, 5, 10, and 30 years to maturity on the indicated variables. In Panel A, the swap spreads are computed as the difference between the fixed rate in an IRS based on Japanese Libor rates and Japanese government bond yields. $\Delta U F R_{t}^{+}$is the change in the underfunding ratio of Japanese pension funds as defined in Equation (6), conditional on pension funds being underfunded at time t. There are no time periods where Japanese pension funds are fully funded. $\Delta L R$ Spread $_{t}$ is the change in the quarter-end difference between the 6-month Japanese Libor rate and 6-month General Collateral repo rate. In Panel B, the swap spreads are computed as the difference between the fixed rate in an IRS based on Euribor and German government bond yields. Under 30 Year (Neth), the swap spread is computed relative to the Dutch government bond yield. $\Delta U F R_{t}^{+}\left(\Delta U F R_{t}^{-}\right)$ is the change in the underfunding ratio of Dutch pension funds as defined in Equation (7), conditional on pension funds being underfunded (funded) at time t. Pension funds are underfunded if the policy funding ratio drops below $105 \%$. The numbers in parenthesis are heteroskedasticity-robust t-statistics. ${ }^{* * *},{ }^{* *}$, and ${ }^{*}$ indicate significance at a 1\%, 5\%, and 10\% level respectively. The observation period is Q1 2005-Q4 2015 for Japan and Q1 2007 - Q4 2014 for the Netherlands.

\begin{tabular}{lccccc}
\hline \multicolumn{5}{c}{ Panel A: Regression analysis for Japan } \\
\hline & 2 Year & 5 Year & 10 Year & 30 Year & \\
\hline Intercept & -0.05 & 0.00 & -0.20 & -1.06 & \\
& $(-0.08)$ & $(0.00)$ & $(-0.28)$ & $(-0.84)$ & \\
$\Delta U F R_{t}^{+}$ & -0.28 & -0.28 & $-1.00^{* * *}$ & $-2.02^{* * *}$ & \\
& $(-1.18)$ & $(-1.02)$ & $(-3.72)$ & $(-4.45)$ & \\
$\Delta L R$ Spread $_{t}$ & $0.23^{* * *}$ & 0.12 & -0.05 & 0.06 & \\
& $(3.04)$ & $(1.01)$ & $(-0.39)$ & $(0.38)$ & \\
\hline Observations & 43 & 43 & 43 & 43 & \\
Adjusted $\mathrm{R}^{2}$ & 0.11 & 0.00 & 0.32 & 0.34 & -0.52 \\
\hline \multicolumn{5}{c}{ Panel B: Regression analysis for the Netherlands } & \\
\hline Intercept & 2 Year & 5 Year & 10 Year & 30 Year & 30 Year (Neth) \\
& 0.98 & 0.72 & -0.29 & -0.90 & $(-0.25)$ \\
$\Delta U F R_{t}^{+}$ & $(0.30)$ & $(0.23)$ & $(-0.14)$ & $(-0.59)$ & $-1.11^{* *}$ \\
& $1.92^{*}$ & 1.65 & 0.89 & $-1.27^{* * *}$ & $(-2.31)$ \\
$\Delta U F R_{t}^{-}$ & $(1.85)$ & $(1.49)$ & $(1.28)$ & $(-4.29)$ & -0.43 \\
& 0.25 & 0.57 & $0.76^{* *}$ & -0.09 & $(-1.17)$ \\
\hline Observations & $(0.27)$ & $(1.15)$ & $(2.42)$ & $(-0.32)$ & 31 \\
Adjusted $R^{2}$ & 0.05 & 0.06 & 0.13 & 0.16 & 0.09 \\
\hline
\end{tabular}

